\title{
The value of adding optics to ecosystem models: a case study
}

\author{
M. Fujii ${ }^{1}$, E. Boss $^{2}$, and F. Chai ${ }^{2}$ \\ ${ }^{1}$ Sustainability Governance Project, Creative Research Initiative "Sousei”, Hokkaido University, N9W8, Kita-ku, Sapporo, \\ Hokkaido 060-0809, Japan \\ ${ }^{2}$ School of Marine Sciences, 5706 Aubert Hall, University of Maine, Orono, ME 04469-5706, USA
}

Received: 5 April 2007 - Published in Biogeosciences Discuss.: 23 May 2007

Revised: 21 August 2007 - Accepted: 25 September 2007 - Published: 11 October 2007

\begin{abstract}
Many ecosystem models have been developed to study the ocean's biogeochemical properties, but most of these models use simple formulations to describe light penetration and spectral quality. Here, an optical model is coupled with a previously published ecosystem model that explicitly represents two phytoplankton (picoplankton and diatoms) and two zooplankton functional groups, as well as multiple nutrients and detritus. Surface ocean color fields and subsurface light fields are calculated by coupling the ecosystem model with an optical model that relates biogeochemical standing stocks with inherent optical properties (absorption, scattering); this provides input to a commercially available radiative transfer model (Ecolight). We apply this bio-optical model to the equatorial Pacific upwelling region, and find the model to be capable of reproducing many measured optical properties and key biogeochemical processes in this region. Our model results suggest that non-algal particles largely contribute to the total scattering or attenuation $(>50 \%$ at $660 \mathrm{~nm}$ ) but have a much smaller contribution to particulate absorption $(<20 \%$ at $440 \mathrm{~nm})$, while picoplankton dominate the total phytoplankton absorption (>95\% at $440 \mathrm{~nm}$ ). These results are consistent with the field observations. In order to achieve such good agreement between data and model results, however, key model parameters, for which no field data are available, have to be constrained. Sensitivity analysis of the model results to optical parameters reveals a significant role played by colored dissolved organic matter through its influence on the quantity and quality of the ambient light. Coupling explicit optics to an ecosystem model provides advantages in generating: (1) a more accurate subsurface lightfield, which is important for light sensitive biogeochemical processes such as photosynthesis and photo-oxidation, (2) additional constraints on model parameters that help to reduce uncertainties in ecosystem model simulations, and (3)
\end{abstract}

Correspondence to: M. Fujii

(mfujii@sgp.hokudai.ac.jp) model output which is comparable to basic remotely-sensed properties. In addition, the coupling of biogeochemical models and optics paves the road for future assimilation of ocean color and in-situ measured optical properties into the models.

\section{Introduction}

Marine ecosystem models have increased their relevance by incorporating greatly enhanced spatial resolution and more sophisticated representations of functional groups (e.g., Rothstein et al., 2006). The models vary from the simplest nutrient/phytoplankton/zooplankton/detritus (NPZD) models (e.g., Riley et al., 1949; Denman and Peña, 2002; Schartau and Oschlies, 2003) to complex models with twenty or more components including different types of plankton, nutrients, and a microbial loop (e.g., Bissett et al., 1999; Moore et al., 2002; Gregg et al., 2003; Lancelot et al., 2005) accompanied with an increase in the number of specified parameters (e.g., Denman, 2003; Friedrichs et al., 2007).

Progress in ocean color remote sensing technology and inversion algorithms has provided ways to assess standing stocks of phytoplankton pigments and carbon (Behrenfeld et al., 2005), particulate organic carbon (POC, Stramski et al., 1999), and colored dissolved organic matter (CDOM, Siegel et al., 2002) through their unique scattering and/or absorption signatures. Global net oceanic primary productivity (carbon fixation) has been estimated with satellite data, based on the derived surface chlorophyll concentration (e.g., Behrenfeld and Falkowski, 1997) and more recently from remote estimation of both phytoplankton carbon and chlorophyll (Behrenfeld et al., 2005). Many of these advances are based on semiempirical algorithms linking ocean color to the optical properties of the underlying constituents (IOCCG, 2006).

Given the ability to measure optical properties from small, robust, and high-frequency sensors in-situ and on a variety of platforms (e.g., Rudnick and Perry, 2003), a large body of

Published by Copernicus Publications on behalf of the European Geosciences Union. 


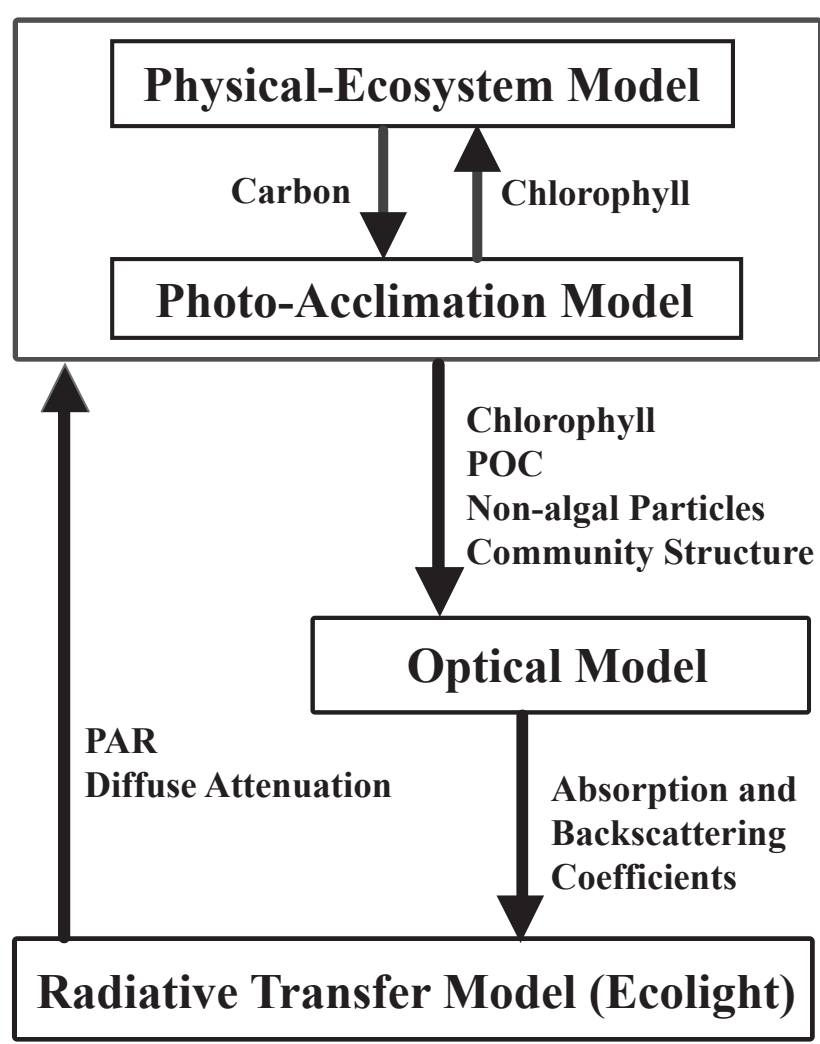

Fig. 1. Schematic view of model used in this study.

work has been assembled linking biogeochemical variables to optical properties (e.g., Dickey et al., 2006).

Considering this progress in observational capabilities, if we are to compare models to measurements and/or assimilate measurements into models, it is imperative to contemplate modeling not only the biogeochemical but also the inherent optical properties (IOP) such as absorption and backscattering as state variables, and to directly compare model results to estimates from remotely observed or in-situ measured quantities. Conversion of biogeochemical properties to optical parameters is also needed to realistically model the underwater light field, which is used as an input to model processes such as photosynthesis and photochemistry. The optical consequences of seawater constituents, including dissolved materials, phytoplankton, and non-algal particles (NAP), need to be included in ecosystem models, and the interaction of light with these materials needs to be computed to obtain realistic depth- and wavelength-resolved light fields. However, with very few exceptions (e.g., Bissett et al., 1999), most ecosystem models do not include the physics and bio-optics associated with the underwater light field. In addition, Rothstein et al. (2006) have specifically recommended the development of ecosystem models which includes optics.

In this study, we develop a multi-nutrient phytoplankton, zooplankton, and detritus ecosystem model with associated wavelength-resolved optical properties. We choose to simulate the equatorial Pacific where data from several programs are available (e.g. Murray et al., 1995; Barber et al., 1996; Dupouy et al., 2003; Gardner et al., 2003; Simeon et al., 2003). We will present in this paper that by adding optical properties in the ecosystem model, the model improves in: (1) having more data to compare model output on model formulation and choice of parameter values, and (2) simulation realism for key biogeochemical processes. Model sensitivity studies to the values of optical parameters will demonstrate the crucial role CDOM plays in phytoplankton dynamics, nutrient cycling, and the light field.

\section{Model description and experimental design}

The bio-optical model constructed in this study consists of four individual models: a physical-ecosystem model (simulating the dynamics of different ecosystem components in time and space), a photo-acclimation model (specifying the chlorophyll to carbon ratio of phytoplankton), an optical model (converting ecosystem state variables into inherent optical properties), and a radiative transfer model (calculating the underwater light field and the ocean color) (Fig. 1). For ease of comparison with data, we demonstrate area-averaged one dimensional (vertical) and time-averaged results. The model, however, is formulated and designed to be used in 4 dimensions.

\subsection{Physical-ecosystem model and photo-acclimation model}

The physical-ecosystem model used in this study is based on the Carbon, Silicon, Nitrogen Ecosystem (CoSINE) model (Chai et al., 2002), which was originally developed to simulate biogeochemical properties in the equatorial Pacific upwelling region. The ecosystem model explicitly represents two phytoplankton (picoplantkon $\mathrm{P} 1\left(\mathrm{mmolN} \mathrm{m}^{-3}\right)$ and diatoms $\mathrm{P} 2\left(\mathrm{mmolN} \mathrm{m}^{-3}\right)$ ) and two zooplankton functional groups (microzooplankton $\mathrm{Z} 1\left(\mathrm{mmolN} \mathrm{m}^{-3}\right)$ and mesozooplantkon $\mathrm{Z} 2\left(\mathrm{mmolN} \mathrm{m}^{-3}\right)$ ), as well as multiple nutrients (nitrate $\mathrm{NO}_{3}\left(\mathrm{mmolN} \mathrm{m}^{-3}\right)$, ammonium $\mathrm{NH}_{4}\left(\mathrm{mmolN} \mathrm{m}^{-3}\right)$, and silicate $\left.\mathrm{Si}(\mathrm{OH})_{4}\left(\mathrm{mmolSi} \mathrm{m}^{-3}\right)\right)$ and detritus (non-algal particles NAP $\left(\mathrm{mmolNm}^{-3}\right)$ and biogenic silica $\mathrm{bSiO}_{2}$ $\left(\mathrm{mmolSi} \mathrm{m}{ }^{-3}\right)$ ) (Fig. 2). Phytoplankton take up $\mathrm{NO}_{3}$ and $\mathrm{NH}_{4}$ by photosynthesis. In addition, diatoms utilize $\mathrm{Si}(\mathrm{OH})_{4}$ in the silicification process. Microzooplankton graze on picoplankton. Mesozooplankton feed on diatoms, microzooplankton, and NAP.

To simulate the observed variation in phytoplanktonic chlorophyll to carbon ratio with growth conditions (light, nutrients, and temperature), we incorporated a photoacclimation model into the physical-ecosystem model. Geider et al. $(1987,1998)$ developed a photo-acclimation model with single nutrient (nitrogen) and single phytoplankton 


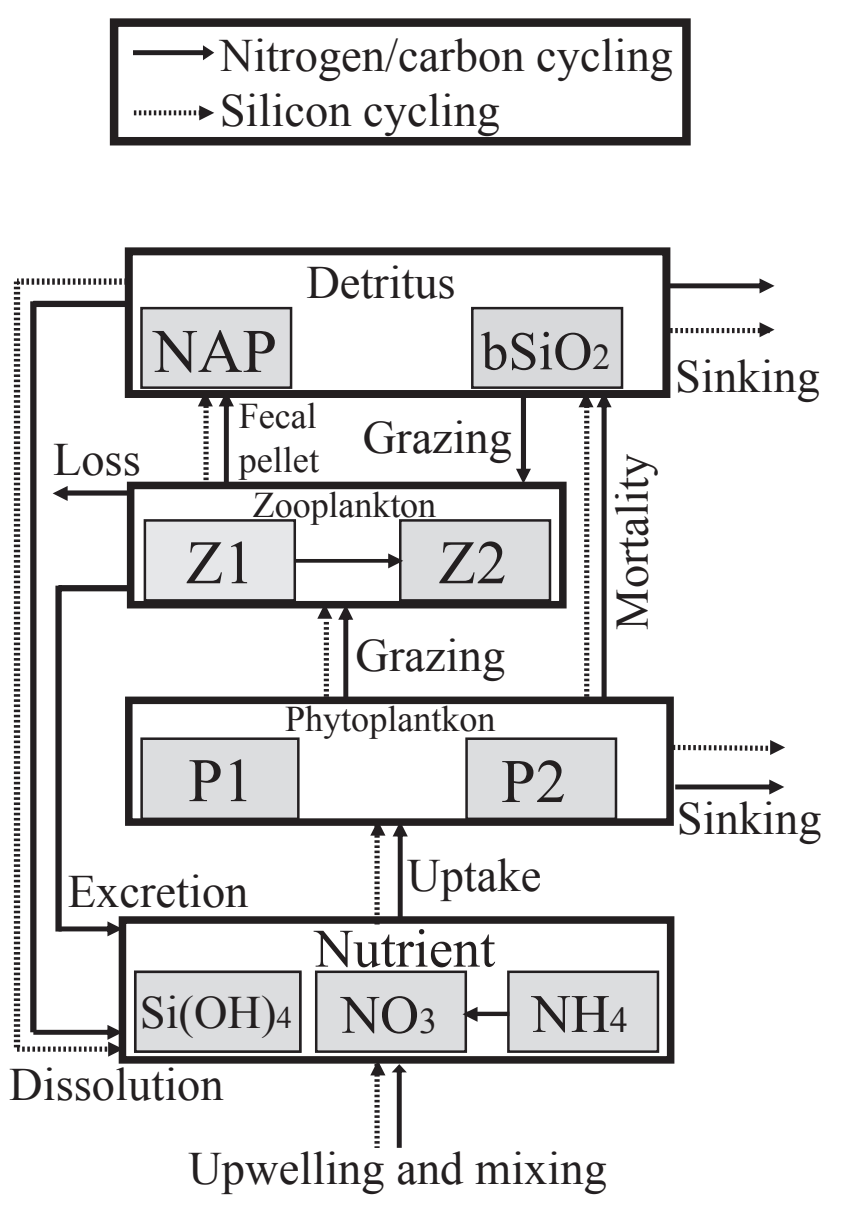

Fig. 2. The inter-compartmental flow chart of the ecosystem and linkage to physical processes. The flows of nitrogen and silicon are indicated by solid and dashed lines, respectively. P1: picoplankton $\left(\mathrm{mmolN} \mathrm{m}^{-3}\right), \mathrm{P} 2$ : diatoms $\left(\mathrm{mmolN} \mathrm{m}^{-3}\right), \mathrm{Z} 1$ : microzooplankon $\left(\mathrm{mmolN} \mathrm{m}{ }^{-3}\right), \mathrm{Z2}$ : mesozooplankton $\left(\mathrm{mmolN} \mathrm{m}^{-3}\right), \mathrm{NO}_{3}$ : nitrate $\left(\mathrm{mmolN} \mathrm{m}^{-3}\right), \mathrm{NH}_{4}$ : ammonium $\left(\mathrm{mmolN} \mathrm{m}^{-3}\right), \mathrm{Si}(\mathrm{OH})_{4}$ : silicate $\left(\mathrm{mmolSi} \mathrm{m}^{-3}\right)$, NAP: non-algal particles $\left(\mathrm{mmolN} \mathrm{m}^{-3}\right)$, and $\mathrm{bSiO}_{2}$ : biogenic silica $\left(\mathrm{mmolSi} \mathrm{m}{ }^{-3}\right)$.

species. The photo-acclimation model used here is based on that of Moore et al. (2002) modified from Geider et al. (1998), which could be embedded in the multi-nutrient, phytoplankton, zooplankton, and detritus ecosystem model.

The governing equations and formulations of physicalecosystem model and photo-acclimation model are described in Appendix A. The biogeochemical parameter values used in this study and their notations are provided in Table 1.

\subsection{Optical model and radiative transfer model}

We developed an optical module that explicitly represents spectrally-resolved inherent optical properties (IOPs, e.g., absorption, scattering, and attenuation) from the ecosystem model variables. Using a radiative-transfer model, we obtain the apparent optical properties (AOPs), such as diffuse (a)

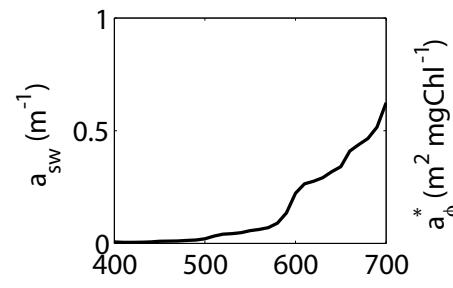

(c)

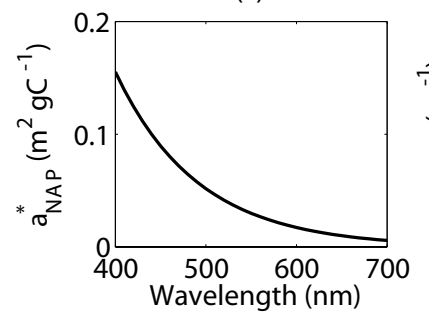

(b)

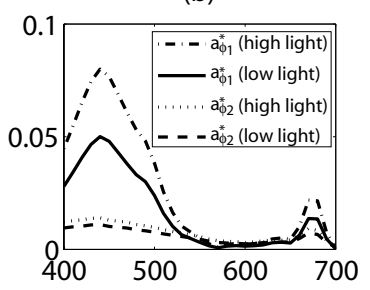

(d)

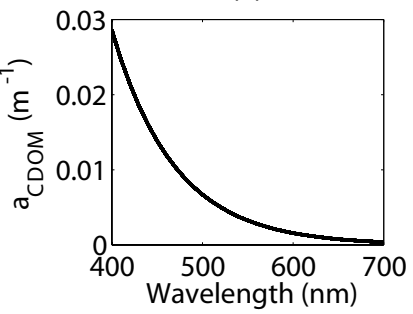

Fig. 3. Modeled (a) absorption coefficient by sea water $a_{s w}\left(\mathrm{~m}^{-1}\right)$, (b) chlorophyll-specific absorption coefficients by picoplankton and diatoms $\left(a_{\phi 1}^{*}\right.$ and $a_{\phi 2}^{*}$, respectively) $\left(\mathrm{m}^{2} \mathrm{mgChl}^{-1}\right)$, (c) carbonspecific absorption coefficient by NAP $\left(\mathrm{m}^{2} \mathrm{gC}^{-1}\right)$, and (d) absorption coefficient by CDOM $\left(\mathrm{m}^{-1}\right)$ from $400 \mathrm{~nm}$ to $700 \mathrm{~nm}$.

attenuation, and radiometric quantities, as well as photosynthetically available radiation (PAR) and remotely sensed reflectance (ocean color).

The absorption coefficient is determined from the sum of the absorption coefficients of seawater, picoplankton and diatoms (based on their chlorophyll content, Chl1 and Chl2, respectively), non-algal particles (NAP), and colored dissolved organic matter (CDOM). Notable differences exist in the chlorophyll-specific absorption coefficient $\left(\mathrm{m}^{2} \mathrm{mg}^{-1}\right)$ of small and large phytoplankton, i.e., small phytoplankton have a higher chlorophyll-specific absorption coefficient and a steeper absorption spectra than large phytoplankton (Bricaud et al., 1983). In addition, the absorption spectra of a given phytoplankton functional group changes with intercellular chlorophyll concentration (the package effect, e.g., Duysens, 1956). Therefore, the chlorophyll-specific absorption coefficients by picoplankton and diatoms, $a_{\phi 1}^{*}$ and $a_{\phi 2}^{*}$, are modeled separately, taking into account their photoadaptive state (e.g., their specific chlorophyll to carbon ratio) as follows (Fig. 3b):

$$
\begin{aligned}
& a_{\phi 1}^{*}(\lambda, z)\left(\mathrm{m}^{2} \mathrm{mg}^{-1}\right)=a_{\phi 1 \text { (high light })}^{*}(\lambda) \\
& \times\left(1-\frac{\frac{\mathrm{Ch} 11(z)}{C 1(z)}-\theta_{\min }^{C}}{\theta_{\max }^{C}-\theta_{\min }^{C}}\right)+a_{\phi 1(\text { low light })}^{*}(\lambda) \times \frac{\frac{\mathrm{Ch} 11(z)}{C 1(z)}-\theta_{\min }^{C}}{\theta_{\max }^{C}-\theta_{\min }^{C}},
\end{aligned}
$$

$$
\begin{aligned}
& a_{\phi 2}^{*}(\lambda, z)\left(\mathrm{m}^{2} \mathrm{mg}^{-1}\right)=a_{\phi 2 \text { (high light) }}^{*}(\lambda) \\
& \times\left(1-\frac{\frac{\mathrm{Ch} 22(z)}{C 2(z)}-\theta_{\min }^{C}}{\theta_{\max }^{C}-\theta_{\min }^{C}}\right)+a_{\phi 2(\text { low light })}^{*}(\lambda) \times \frac{\frac{\mathrm{Ch} 2(z)}{C 2(z)}-\theta_{\min }^{C}}{\theta_{\max }^{C}-\theta_{\min }^{C}},
\end{aligned}
$$


Table 1. The model parameters and values. Columns Case 1-1, Case 1-2, and Case 2 denote the parameter values used in non-spectral ecosystem model (Cases 1-1 and 1-2, without optics) and bio-optical model (Case 2), respectively.

\begin{tabular}{|c|c|c|c|c|c|c|c|}
\hline Parameters & Symbol & Chai et al. (2002) & Case 1-1 & Case 1-2 & Case 2 & Unit & Reference \\
\hline \multicolumn{8}{|l|}{ For ecosystem model } \\
\hline Light attenuation coefficient due to water & $k_{1}$ & 0.046 & 0.046 & 0.053 & N/A & $\mathrm{m}^{-1}$ & (1) \\
\hline Light attenuation coefficient by chlorophyll & $k_{2}$ & 0.048 & 0.048 & 0.064 & N/A & $\left(\mathrm{mgChl} \mathrm{m}{ }^{-3}\right)^{-1}$ & (1) \\
\hline $\mathrm{NH}_{4}$ inhibition parameter & $\Psi$ & 5.59 & 5.59 & 5.59 & 5.59 & $\left.(\mathrm{mmolN} \mathrm{m})^{-3}\right)^{-1}$ & (1) \\
\hline Half-saturation for $\mathrm{NO}_{3}$ uptake by picoplankton & $K_{\mathrm{NO}_{3}}$ & 1.0 & 1.0 & 1.0 & 1.0 & $\mathrm{mmolN} \mathrm{m}^{-3}$ & (1) \\
\hline Half-saturation for $\mathrm{NH}_{4}$ uptake by picoplankton & $K_{\mathrm{NH}_{4}}$ & 0.05 & 0.05 & 0.05 & 0.05 & $\mathrm{mmolN} \mathrm{m}^{-3}$ & (1) \\
\hline Half-saturation for $\mathrm{Si}(\mathrm{OH})_{4}$ uptake & $K_{\mathrm{Si}(\mathrm{OH})_{4}}$ & 3.0 & 3.0 & 3.0 & 3.0 & $\mathrm{mmolSi} \mathrm{m}^{-3}$ & (1) \\
\hline Half-saturation for $\mathrm{NH}_{4}$ uptake by diatoms & $K_{P 2} \mathrm{NH}_{4}$ & 1.0 & 1.0 & 1.0 & 1.0 & $\mathrm{mmolN} \mathrm{m}^{-3}$ & (1) \\
\hline Diatom sinking speed & $W_{1}$ & 1.0 & 1.0 & 1.0 & 1.0 & $\mathrm{~m} \mathrm{day}^{-1}$ & (1) \\
\hline Microzooplankton maximum specific grazing rate & $G 1_{\max }$ & 1.35 & 1.6 & 1.35 & 1.35 & day $^{-1}$ & (1) \\
\hline Microzooplankton assimilation efficiency & $\gamma_{0}$ & 1.0 & 1.0 & 1.0 & 1.0 & dimensionless & (1) \\
\hline Half-saturation for microzooplankton ingestion & $K 1_{g r}$ & 0.5 & 0.5 & 0.5 & 0.5 & $\mathrm{mmolNm}^{-3}$ & (1) \\
\hline Microzooplankton excretion rate to $\mathrm{NH}_{4}$ & reg 1 & 0.2 & 0.2 & 0.2 & 0.2 & $\mathrm{day}^{-1}$ & (1) \\
\hline Mesozooplankton maximum specific grazing rate & $G 2_{\max }$ & 0.64 & 0.64 & 0.64 & 0.64 & day $^{-1}$ & (2) \\
\hline Mesozooplankton assimilation efficiency & $\gamma_{1}$ & 0.75 & 0.75 & 0.75 & 0.75 & dimensionless & (1) \\
\hline $\begin{array}{l}\text { Half-saturation for mesozooplankton ingestion for } \\
\text { diatoms, microzooplankton, and NAP }\end{array}$ & $K 2_{g r}$ & 0.25 & 0.25 & 0.25 & 0.25 & $\mathrm{mmolN} \mathrm{m}^{-3}$ & (1) \\
\hline Diatom-specific mortality rate & $\gamma_{3}$ & 0.05 & 0.05 & 0.05 & 0.05 & day $^{-1}$ & (1) \\
\hline Mesozooplankton-specific mortality rate & $\gamma_{2}$ & 0.05 & 0.05 & 0.05 & 0.05 & day $^{-1}$ & (1) \\
\hline Mesozooplankton excretion rate to $\mathrm{NH}_{4}$ & $\mathrm{reg}_{2}$ & 0.1 & 0.1 & 0.1 & 0.1 & $\mathrm{day}^{-1}$ & (1) \\
\hline Grazing preference for diatoms & $\rho_{1}$ & 0.7 & 0.7 & 0.7 & 0.7 & dimensionless & (1) \\
\hline Grazing preference for microzooplankton & $\rho_{2}$ & 0.2 & 0.2 & 0.2 & 0.2 & dimensionless & (1) \\
\hline Grazing preference for NAP & $\rho_{3}$ & 0.1 & 0.1 & 0.1 & 0.1 & dimensionless & (1) \\
\hline NAP remineralization rate & $\gamma_{7}$ & 0.0 & 0.0 & 0.0 & 0.0 & $\mathrm{day}^{-1}$ & (1) \\
\hline $\mathrm{bSiO}_{2}$ dissolution rate & $\gamma_{4}$ & 0.0 & 0.0 & 0.0 & 0.0 & day $^{-1}$ & (1) \\
\hline NAP sinking speed & $W_{2}$ & 10.0 & 10.0 & 10.0 & 10.0 & $\mathrm{~m}_{\mathrm{day}}{ }^{-1}$ & (1) \\
\hline $\mathrm{bSiO}_{2}$ sinking speed & $W_{4}$ & 20.0 & 20.0 & 20.0 & 20.0 & $\mathrm{~m} \mathrm{day}^{-1}$ & (1) \\
\hline Diatom Si:N uptake ratio & $R_{\mathrm{SiN}}$ & 1.0 & 1.0 & 1.0 & 1.0 & $\operatorname{molSi}(\mathrm{molN})^{-1}$ & (1) \\
\hline Nitrification rate & $\gamma_{5}$ & 0.0 & 0.0 & 0.0 & 0.0 & day $^{-1}$ & (1) \\
\hline Ratio of carbon to nitrogen in phytoplankton & $R_{\mathrm{CN}}$ & 6.625 & 6.625 & 6.625 & 6.625 & $\operatorname{molC}(\mathrm{molN})^{-1}$ & (1) \\
\hline \multicolumn{8}{|l|}{ For photo-acclimation model } \\
\hline $\begin{array}{l}\text { Chlorophyll-specific initial slope of P vs. I curve for } \\
\text { phytoplankton }\end{array}$ & $\alpha$ & N/A & 0.25 & 0.25 & 0.25 & $\mathrm{molC} \mathrm{m}^{2}(\mathrm{gChl} \mathrm{W} \text { day })^{-1}$ & (3) \\
\hline Minimum phytoplankton nitrogen:carbon ratio & $Q_{\min }$ & N/A & 0.034 & 0.034 & 0.034 & $\mathrm{molN} \mathrm{molC}^{-1}$ & (4) \\
\hline Maximum phytoplankton nitrogen:carbon ratio & $Q_{\max }$ & N/A & 0.17 & 0.17 & 0.17 & $\mathrm{molN} \mathrm{molC}^{-1}$ & (4) \\
\hline $\begin{array}{l}\text { Maximum picoplankton carbon-specific nitrogen- } \\
\text { uptake rate at temperature } T_{\text {ref }}\end{array}$ & $P_{\text {ref }}^{C 1}$ & N/A & 2.0 & 2.0 & 2.0 & day $^{-1}$ & (3) \\
\hline $\begin{array}{l}\text { Maximum diatom carbon-specific nitrogen-uptake } \\
\text { rate at temperature } T_{\text {ref }}\end{array}$ & $P_{\mathrm{ref}}^{C 2}$ & N/A & 3.0 & 3.0 & 3.0 & day $^{-1}$ & (3) \\
\hline Maximum value of $\theta^{N}$ & $\theta_{\max }^{N}$ & N/A & 4.2 & 4.2 & 4.2 & $\mathrm{gChl} \mathrm{molN}{ }^{-1}$ & (4) \\
\hline Cost of biosynthesis & $\xi_{\mathrm{NO}_{3}}$ & N/A & 2.33 & 2.33 & 2.33 & $\mathrm{molC} \mathrm{molN}^{-1}$ & (4) \\
\hline Slope of an Arrehenius plot & $E a / R$ & N/A & 4000 & 4000 & 4000 & $\mathrm{~K}$ & (3) \\
\hline Reference temperature & $T_{\text {ref }}$ & N/A & 303.15 & 303.15 & 303.15 & K & (3) \\
\hline \multicolumn{8}{|l|}{ For optical model } \\
\hline Minimum phytoplankton chlorophyll to carbon ratio & $\theta_{\min }^{C}$ & N/A & N/A & N/A & 0.036 & $\mathrm{mgChl} \mathrm{mmolC}{ }^{-1}$ & (5), (6), (7) \\
\hline Maximum phytoplankton chlorophyll to carbon ratio & $\theta_{\max }^{C}$ & N/A & N/A & N/A & 1.2 & $\mathrm{mgCh} l \mathrm{mmolC}^{-1}$ & $(5),(6),(7)$ \\
\hline $\begin{array}{l}\text { Carbon-specific absorption coefficient by NAP at } \\
440 \mathrm{~nm}\end{array}$ & $a_{\mathrm{NAP}}^{+}(440)$ & N/A & N/A & N/A & 0.1 & $\mathrm{~m}^{2} \mathrm{gC}^{-1}$ & $(8),(9)$ \\
\hline Absorption coefficient by CDOM at $440 \mathrm{~nm}$ & $a_{\mathrm{CDOM}}(440)$ & N/A & N/A & N/A & 0.016 & $\mathrm{~m}^{-1}$ & (10) \\
\hline Background backscattering coefficient & $b_{b b g}$ & N/A & N/A & N/A & 0.00017 & $\mathrm{~m}^{-1}$ & (11) \\
\hline Ratio of phytoplankton carbon to POC & $R_{\mathrm{POC}}^{\phi}$ & N/A & N/A & N/A & 0.3 & dimensionless & $(12),(13),(14),(15)$ \\
\hline Backscattering ratio for picoplankton & $\tilde{b}_{b_{-} P 1}$ & N/A & N/A & N/A & 0.01 & dimensionless & (16) \\
\hline Backscattering ratio for diatoms & $\tilde{b}_{b_{-} P 2}$ & N/A & N/A & N/A & 0.006 & dimensionless & (17), (18) \\
\hline Backscattering ratio for NAP & $\tilde{b}_{b \_ \text {NAP }}$ & N/A & N/A & N/A & 0.015 & dimensionless & (16) \\
\hline Backscattering ratio for background particles & $\tilde{b}_{b \_b b g}$ & N/A & N/A & N/A & 0.02 & dimensionless & (16) \\
\hline Backscattering ratio for sea water & $\tilde{b}_{b_{-} s w}$ & N/A & N/A & N/A & 0.5 & dimensionless & (18) \\
\hline
\end{tabular}

References noted here are: (1) Chai et al., 2002; (2) this study; (3) Moore et al., 2002; (4) Geider et al., 1998; (5) Falkowski et al., 1985; (6) Geider et al., 1987; (7) Cloern et al., 1995; (8) Babin et al., 2003a; (9) Babin et al., 2003b; (10) Simeon et al , 2003; (11) Behrenfeld and Boss, 2006; (12) Eppley et al., 1992; (13) DuRand et al., 2001; (14) Gundersen et al., 2001; (15) Oubelkheir et al., 2001; (16) Twardowski et al., 2001; (17) Boss et al., 2004 ; (18) Morel, 1974.

where $a_{\phi 1 \text { (high light) }}^{*}(\lambda), a_{\phi 1 \text { (low light) }}^{*}(\lambda), a_{\phi 2 \text { (high light) }}^{*}(\lambda)$, and $a_{\phi 2 \text { (low light) }}^{*}(\lambda)$ are chlorophyll-specific absorption coefficients at low and high light by each phytoplankton, respectively, derived as described in Appendix B. $\theta_{\min }^{C}$ and $\theta_{\max }^{C}$ are the minimum and maximum phytoplanktonic chlorophyll to carbon ratios which are set to be $0.036\left(\mathrm{mgChl} \mathrm{mmolC}^{-1}\right)$ and $1.2\left(\mathrm{mgChl} \mathrm{mmolC}^{-1}\right)$, respectively, based on measurements in phytoplankton cultures (e.g., Falkowski et al., 1985; Geider et al., 1987; Cloern et al., 1995). The absorption co- 
efficient by total phytoplankton $a_{\phi}$ is:

$a_{\phi}(\lambda, z)\left(\mathrm{m}^{-1}\right)=a_{\phi 1}^{*}(\lambda, z) \times \operatorname{Chl1}(z)+a_{\phi 2}^{*}(\lambda, z) \times \operatorname{Chl} 2(z)$.

Based on observations (e.g., Iturriaga and Siegel, 1989; Roesler et al., 1989), the absorption coefficient by NAP $\left(a_{\mathrm{NAP}}\right)$ is formulated as:

$a_{\mathrm{NAP}}(\lambda, z)\left(\mathrm{m}^{-1}\right)=a_{\mathrm{NAP}}^{+}(440) \times \mathrm{NAP}(z) \times R_{\mathrm{CN}} \times 12.0$

$\times 0.001 \times \exp \{-0.011 \times(\lambda-440)\}$,

where $a_{\mathrm{NAP}}^{+}(440)$ is the carbon-specific absorption coefficient by NAP at $440 \mathrm{~nm}$, assumed to be $0.1\left(\mathrm{~m}^{2} \mathrm{gC}^{-1}\right)$ based on results of $a_{\mathrm{NAP}}(440) /\left[\right.$ dry mass] $\sim 0.036 \pm 0.025\left(\mathrm{~m}^{2} \mathrm{~g}^{-1}\right)$ (Babin et al., 2003b; Table 5), and using a conversion of $2.6\left(\mathrm{~g} \mathrm{gC}^{-1}\right)$ (Babin et al., 2003a). Note that modeled NAP is in nitrogen $\left(\mathrm{mmol} \mathrm{m}^{-3}\right)$ and is converted to carbon unit $\left(\mathrm{gC} \mathrm{m}^{-3}\right)$. $R_{\mathrm{CN}}$ is the ratio of carbon to nitrogen in phytoplankton (Table 1).

The total absorption coefficient by particles $a_{p}$ is then calculated:

$a_{p}(\lambda, z)=a_{\phi}(\lambda, z)+a_{\mathrm{NAP}}(\lambda, z)$.

Although effects of dissolved material on absorption in equatorial regions cannot be neglected (e.g., Pegau, 1997; Bricaud et al., 2002; Simeon et al., 2003), information concerning the distribution of CDOM in the equatorial Pacific is scarce. In addition, ratios of CDOM to dissolved organic matter (DOM) or DOM to dissolved organic carbon (DOC) are highly variable regionally (Mueller and Lange, 1989; Siegel et al., 2002). In this study, because CDOM is not explicitly treated in the model, the absorption coefficient by CDOM $\left(a_{\mathrm{CDOM}}\right)$ is assumed constant vertically and with a spectral dependence of (Fig. 3d):

$a_{\mathrm{CDOM}}(\lambda)\left(\mathrm{m}^{-1}\right)=a_{\mathrm{CDOM}}(440) \times \exp \{-0.0145 \times(\lambda-440)\},(6)$

where $a_{\mathrm{CDOM}}(440)$ is the absorption coefficient of CDOM at $440 \mathrm{~nm}$ and the value is fixed to $0.016\left(\mathrm{~m}^{-1}\right)$ in this study, following observational values in the equatorial $\mathrm{Pa}-$ cific (0.012-0.019; Simeon et al., 2003).

Although the observed ratios of backscattering to scattering by particles $\left(b_{b p} / b_{p}\right)$ are relatively low (0.5-3\%) (e.g., Twardowski et al., 2001), backscattering plays an important role in ocean optics in general, and especially in determining ocean color. Assuming no contribution of CDOM to backscattering (e.g., Stramski et al., 2004), backscattering coefficients by algae and the co-varying particles are expressed as a function of POC concentration of small and large particles (POC1 and POC2, respectively) $\left(\mathrm{mg} \mathrm{m}^{-3}\right)$, which consist of algal and associated NAP related to small and large phytoplankton functional groups, respectively. Results from previous studies indicate that the ratio of phytoplankton carbon to POC ( $R_{\mathrm{POC}}^{\phi}$ ) varies between about $25 \%$ and $40 \%$ in space and time (e.g., Eppley et al., 1992; DuRand et al., 2001; Gundersen et al., 2001; Oubelkheir et al., 2005). Considering these studies, we fix the ratio of picoplankton carbon to POC1 and diatom carbon to POC2 to 0.3 . Backscattering by small and large POC (POC1 and POC2), $b_{b p 1}$ and $b_{b p 2}$, are formulated as follows (based on Fig. $4 \mathrm{~b}$ in Stramski et al., 1999):

$b_{b p 1}(\lambda, z)\left(\mathrm{m}^{-1}\right)=\left(\frac{\operatorname{POC} 1(z)}{476935.8}\right)^{\frac{1}{1.277}} \times\left(\frac{\lambda}{510}\right)^{-0.5}$,

$b_{b p 2}(\lambda, z)\left(\mathrm{m}^{-1}\right)=\left(\frac{\operatorname{POC} 2(z)}{17069.0}\right)^{\frac{1}{0.859}}$.

Backscattering by total particles $b_{b p}$ is expressed:

$b_{b p}(\lambda, z)\left(\mathrm{m}^{-1}\right)=b_{b p 1}(\lambda, z)+b_{b p 2}(\lambda, z)+b_{b b g}$,

where $b_{b b g}$ is the background backscattering coefficient that implicitly reflects contribution by non-phytoplanktoncovarying bacteria and other particles and was fixed to $0.00017\left(\mathrm{~m}^{-1}\right)$, which is calculated using backscattering coefficients from Stramski and Kiefer (1991) and a field-based background heterotrophic bacterial concentration of $7 \times 10^{11}$ $\left(\mathrm{m}^{-3}\right)$ from Cho and Azam (1990) (as in Behrenfeld and Boss, 2006).

Total scattering by particles $b_{p}$ is calculated as follows:

$$
\begin{aligned}
& b_{p}(\lambda, z)=R_{\mathrm{POC}}^{\phi} \times \tilde{b}_{b_{-} P 1} \times b_{b p 1}(\lambda, z)+R_{\mathrm{POC}}^{\phi} \times \tilde{b}_{b_{-} P 2} \times b_{b p 2}(\lambda, z) \\
& \quad+\left(1-R_{\mathrm{POC}}^{\phi}\right) \times \tilde{b}_{b_{-} \mathrm{NAP}} \times\left(b_{b p 1}(\lambda, z)+b_{b p 2}(\lambda, z)\right) \\
& \quad+\tilde{b}_{b \_b g} \times b_{b b g}(\lambda, z)
\end{aligned}
$$

where $\tilde{b}_{b_{-} P 1}, \tilde{b}_{b_{-} P 2}, \tilde{b}_{b_{-} \mathrm{NAP}}$, and $\tilde{b}_{b \_b g}$ are the backscattering ratios for picoplankton ( 0.01 ; based on near surface observations in open-ocean waters in Twardowski et al., 2001), diatoms (0.006; based on near-surface coastal observations in Twardowski et al., 2001 and Boss et al., 2004), NAP (0.015; e.g., Twardowski et al., 2001) and other background particles (0.02; e.g., Twardowski et al., 2001), respectively.

Beam attenuation coefficient by particles $c_{p}$ is expressed as follows:

$c_{p}(\lambda, z)\left(\mathrm{m}^{-1}\right)=a_{p}(\lambda, z)+b_{p}(\lambda, z)$.

Total absorption, scattering, and backscattering coefficients, $a, b$ and $b_{b}$, are calculated

$a(\lambda, z)\left(\mathrm{m}^{-1}\right)=a_{s w}(\lambda)+a_{p}(\lambda, z)+a_{\mathrm{CDOM}}(\lambda)$,

$b(\lambda, z)\left(\mathrm{m}^{-1}\right)=b_{s w}(\lambda)+b_{p}(\lambda, z)$,

$b_{b}(\lambda, z)\left(\mathrm{m}^{-1}\right)=\tilde{b}_{b \_s w} \times b_{s w}(\lambda)+b_{b p}(\lambda, z)$,

where $a_{s w}$ and $b_{s w}$ are absorption and backscattering coefficients by seawater, respectively. The coefficients depend on wavelengths and are obtained from Pope and Fry (1997) with the correction for salts (Morel, 1974; Boss and Pegau, 2001) (Figs. 3a and $4 \mathrm{a}) . \tilde{b}_{b_{-} s w}$ is the backscattering ratio for sea water (0.5; e.g. Morel 1974). 
(a)
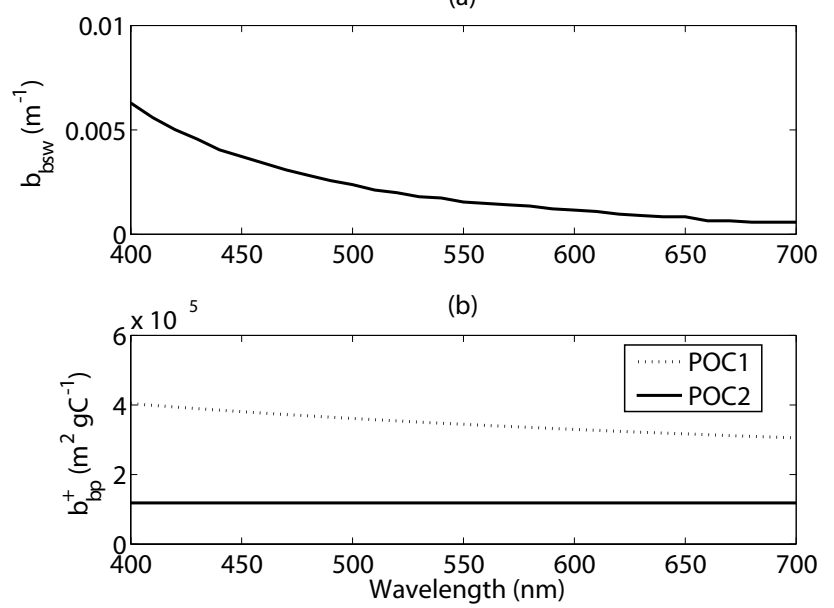

Fig. 4. Modeled (a) backscattering coefficient by sea water $b_{b s w}$ $\left(\mathrm{m}^{-1}\right)$ and (b) carbon-specific backscattering coefficients $b_{b p}^{+}$by small POC (POC1) and large POC (POC2) from $400 \mathrm{~nm}$ to $700 \mathrm{~nm}$.

The model-derived spectral absorption, a Fournier-Forand phase function with the model-derived particulate backscattering ratio (Fournier and Forand, 1994; Mobley et al., 2002), and sky and surface wave conditions, are all input into a radiative transfer model which calculates the underwater light field from which the downwelling photosynthetically available radiation (PAR) $\left(\mathrm{W} \mathrm{m}^{-2}\right)$ is obtained and used as an input to light-sensitive processes in the ecosystem model. For a radiative transfer model, we used Ecolight (Sequoia Scientific, Inc.), a new and reduced version of the Hydrolight radiative transfer model (see Mobley and Sundman (2005a, b) for details of Ecolight). In Ecolight, the radiance is azimuthally averaged and is used to reduce the computation load. A semi-empirical sky model based on RADTRAN (Gregg and Carder, 1990), which is embedded in Ecolight, is used to calculate the hourly irradiance at the sea surface for the appropriate date and location, assuming no cloud cover and a surface wave field consistent with a daily-averaged wind speed of $5 \mathrm{~m} \mathrm{~s}^{-1}$.

\subsection{Experimental design}

The physical-ecosystem simulation model, photoacclimation model, optical model and radiative transfer model (Ecolight) are linked (Fig. 1) and applied to the equatorial Pacific upwelling region $\left(5^{\circ} \mathrm{S}-5^{\circ} \mathrm{N}, 90^{\circ}-180^{\circ} \mathrm{W}\right.$, the "Wyrtki Box"; Wyrtki, 1981). The physical forcing and most of the biogeochemical parameter values are the same as in Chai et al. (2002) (Table 1), although the photo-acclimation model was not introduced by Chai et al. (2002). Hourly incident sky radiance on 30 June, which represents well the annual-mean condition in this oceanic region, is used to drive Ecolight. The short time step of the model (three hours) is needed to simulate diurnal cycles of biology, particularly for

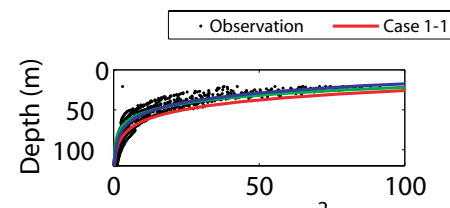

(a) PAR $\left(\mathrm{W} \mathrm{m}^{-2}\right)$

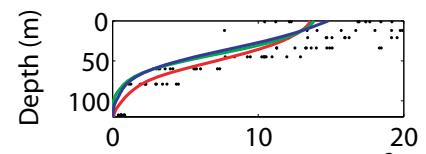

c) Net comm. prod. $\left(\mathrm{mgC} \mathrm{m}^{-3} \mathrm{day}^{-1}\right)$

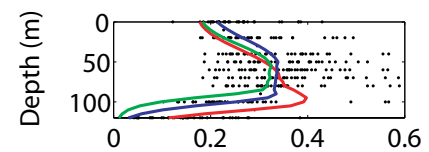

(e) Chlorophyll ( $\mathrm{mg} \mathrm{m}^{-3}$ )

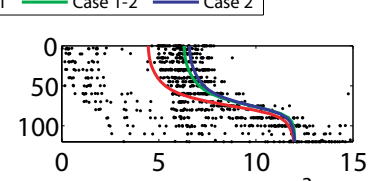

(b) $\mathrm{NO}_{3}\left(\mathrm{mmol} \mathrm{m}^{-3}\right)$

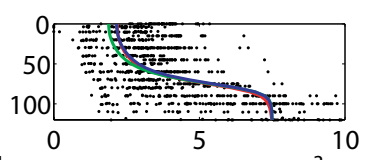

(d) $\mathrm{Si}(\mathrm{OH})_{4}\left(\mathrm{mmol} \mathrm{m}^{-3}\right)$

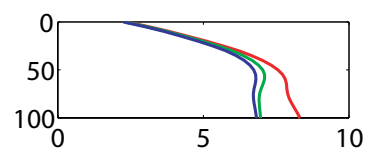

(f) Non algal particles $\left(\mathrm{mg} \mathrm{m}^{-3}\right)$
Fig. 5. Modeled vertical profile of (a) $\mathrm{PAR}\left(\mathrm{W} \mathrm{m}^{-2}\right)$, (b) $\mathrm{NO}_{3}$ $\left(\mathrm{mmolN} \mathrm{m}{ }^{-3}\right)$, (c) net community production $\left(\mathrm{mgC} \mathrm{m}^{-3} \mathrm{day}^{-1}\right)$, (d) $\mathrm{Si}(\mathrm{OH})_{4}\left(\mathrm{mmolSi} \mathrm{m}^{-3}\right)$, (e) chlorophyll $\left(\mathrm{mgChl} \mathrm{m}^{-3}\right)$, and (f) non-algal particles NAP $\left(\mathrm{mgC} \mathrm{m}^{-3}\right)$ in Cases $1-1$ (without optics), 1-2 (without optics), and 2 (with optics). Dots denote the U.S. JGOFS EqPac observations in August-September (Survey II; TT011) and October (Time series II; TT012) of 1992 (Murray et al., 1995; Barber et al., 1996).

phytoplankton, because the photosynthesis is controlled by irradiance at each time step. We tested increasing the time step and found that it could be no longer than three hours before significant differences were observed. Shorter time steps did not change the simulation markedly and would represent an undesirable increase in computation load.

Next, steady-state results, obtained by running the model up to 1000 days with the area-averaged $\left(5^{\circ} \mathrm{S}-5^{\circ} \mathrm{N}, 90^{\circ} \mathrm{W}-\right.$ $180^{\circ}$ ) annual-mean vertical velocity from the ocean general circulation model (Chai et al., 1996) and the areaaveraged $\left(5^{\circ} \mathrm{S}-5^{\circ} \mathrm{N}, 90^{\circ} \mathrm{W}-180^{\circ}\right)$ annual-mean vertical diffusivity based upon the formulation by Pacanowski and Philander (1981) (Fig. 1 in Chai et al., 2002), are compared to measurements in the equatorial Pacific.

We set all the parameter values in the photo-acclimation model to the same as in previous studies (Geider et al., 1998; Moore et al., 2002) (Table 1). Most of the parameter values in the ecosystem model are set to the same as in Chai et al. (2002). Given that the maximum specific grazing rate by mesozooplankton $\left(\mathrm{G} 2_{\max }\right)$ has a relatively large uncertainty in its value, and the estimated value differs among previous studies with the same ecosystem model (Chai et al., 2002; Jiang et al., 2003; Fujii and Chai, 2007), we modify this parameter's value (tune it) so that the modeled surface nitrate and silicate concentrations would be the closest to the standard measurements in the equatorial Pacific of 6 $\left(\mathrm{mmolN} \mathrm{m}^{-3}\right)$ and $3\left(\mathrm{mmolSi} \mathrm{m}{ }^{-3}\right)$, respectively (Figs. $5 \mathrm{~b}$, d), which were derived from the US JGOFS EqPac observation in August-September (Survey II; TT011) and October 


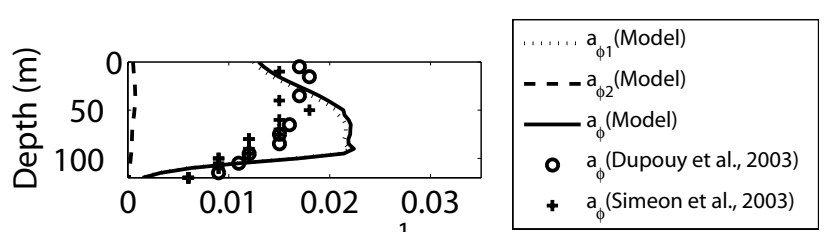

(a) $a_{\phi}(440)\left(m^{1}\right)$
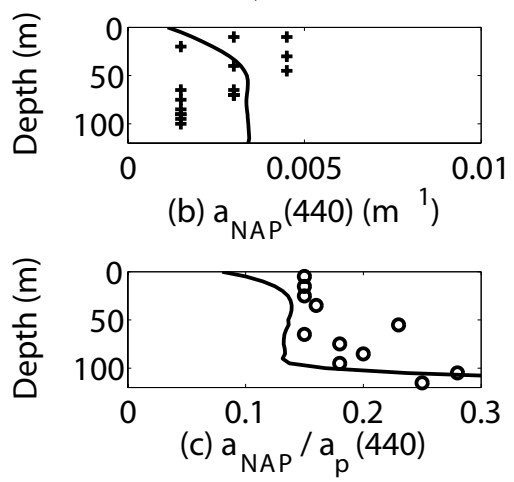

Fig. 6. Modeled vertical profile of (a) absorption coefficients at $440 \mathrm{~nm}$ by picoplankton P1 $\left(a_{\phi 1}(440)\right)$, diatoms P2 $\left(a_{\phi 2}(440)\right)$, and total phytoplankton $(\mathrm{P} 1+\mathrm{P} 2)\left(a_{\phi}(440)\right)\left(\mathrm{m}^{-1}\right)$, (b) absorption coefficient at $440 \mathrm{~nm}$ by non-algal particles NAP $\left(a_{\mathrm{NAP}}(440)\right)\left(\mathrm{m}^{-1}\right)$, and (c) ratio of NAP absorption to total particle absorption at $440 \mathrm{~nm}\left(a_{\mathrm{NAP}} / a_{P}(440)\right)$. Open dots denote observations of Dupouy et al. (2003) (vertically averaged over $10 \mathrm{~m}$ ) and crosses denote observations of Simeon et al. (2003).

(Time series II; TT012) of 1992 (Murray et al., 1995; Barber et al., 1996; Chai et al., 2002). In addition, the model results are examined to reproduce the following observations: (1) values and the types of decrease with depth for PAR and net community production (Figs. 5a, c); (2) maximal chlorophyll concentration of ca. $0.4\left(\mathrm{mgChl} \mathrm{m}^{-3}\right)$ in the subsurface layer at $50 \mathrm{~m}$; and (3) characteristically small NAP contribution to the total particle absorption in the euphotic layer of $10-17 \%$ (Fig. 6b). The tuning continued until all the observed biooptical features in this region are reproduced by the model (see below).

\section{Results and discussion}

\subsection{Bio-optical model results}

\subsubsection{Biological properties}

With the parameter values obtained by the procedure described in the previous subsection (Table 1), the tuned model is capable of reproducing well the measured vertical features in biogeochemical properties in the equatorial Pacific upwelling region, i.e., consistently higher $\mathrm{NO}_{3}$ than $\mathrm{Si}(\mathrm{OH})_{4}$ concentration and surface maximum in net community production (blue lines in Figs. 5b-d; e.g., Barber et al., 1996).

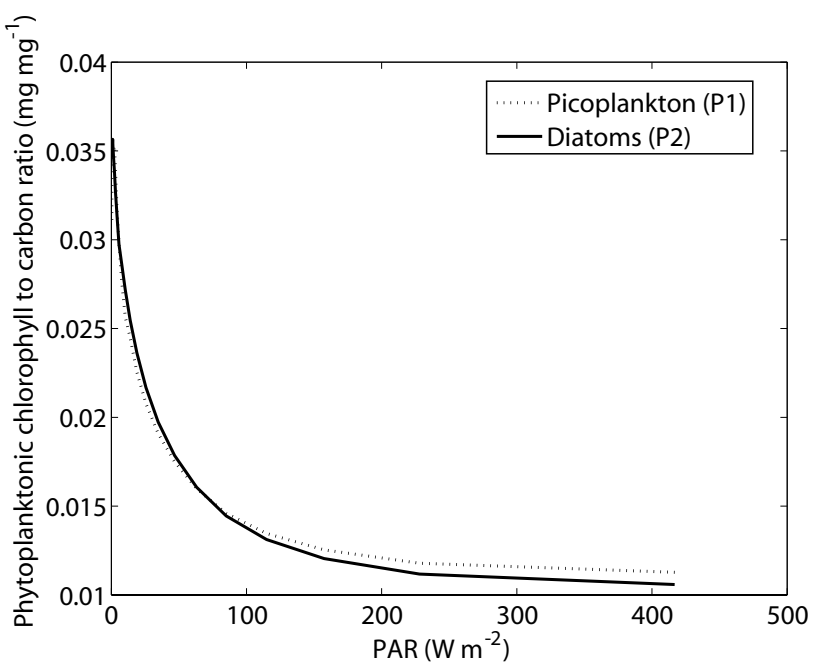

Fig. 7. Modeled phytoplanktonic chlorophyll to carbon ratio $\left(\mathrm{mg} \mathrm{mg}^{-1}\right)$ versus PAR $\left(\mathrm{W} \mathrm{m}^{-2}\right)$ by picoplankton $\mathrm{P} 1$ and diatoms P2.

The model also reproduces a subsurface chlorophyll maximum of $0.34\left(\mathrm{mgChl} \mathrm{m}^{-3}\right)$ at around $65-70 \mathrm{~m}$ depth (blue line in Fig. 5e), which agrees with the observed maximal value of $0.4\left(\mathrm{mgChl} \mathrm{m}^{-3}\right)$ (Dupouy et al., 2003). The modeled phytoplanktonic chlorophyll to carbon ratio decreases with PAR, or increases exponentially with depth (Fig. 7), which is also consistent with observations (e.g., Chavez et al., 1991).

\subsubsection{Optical properties}

\section{Absorption}

Modeled absorption by phytoplankton at $440 \mathrm{~nm}\left(a_{\phi}(440)\right)$ has its subsurface maximum of $0.023\left(\mathrm{~m}^{-1}\right)$ (Fig. 6a), which agrees well with observations $(0.021 \pm 0.001$ (Simeon et al., 2003 ) and $0.023\left(\mathrm{~m}^{-1}\right)$ (Dupouy et al., 2003)). The modeled absorption maximum appears at around $70-95 \mathrm{~m}$ depth, which is deeper than the chlorophyll maximum (blue line in Fig. 5e, and Fig. 6a). This is because chlorophyll absorption is mostly contributed by picoplankton (P1), which has its maximum chlorophyll at deeper layers than diatoms (P2) (Fig. 6a). Modeled contribution of picoplankton to phytoplankton absorption varies between 90 and $98 \%$ in the euphotic layer, which is consistent with the value of $97 \%$ reported for this region (Dupouy et al., 2003).

Modeled absorption by NAP at $440 \mathrm{~nm}\left(a_{\mathrm{NAP}}(440)\right)$ increases with depth and has a maximum of $0.0035\left(\mathrm{~m}^{-1}\right)$ (Fig. 6a). The vertical profile corresponds to that of the NAP concentration (Fig. 5f) and the maximal value is consistent with a measured high value of $0.003\left(\mathrm{~m}^{-1}\right)$ (Dupouy et al., 2003). The absorption by NAP is lower than that of picoplankton $\left(a_{\phi 1}(440)\right)$ but is higher than that of di- 


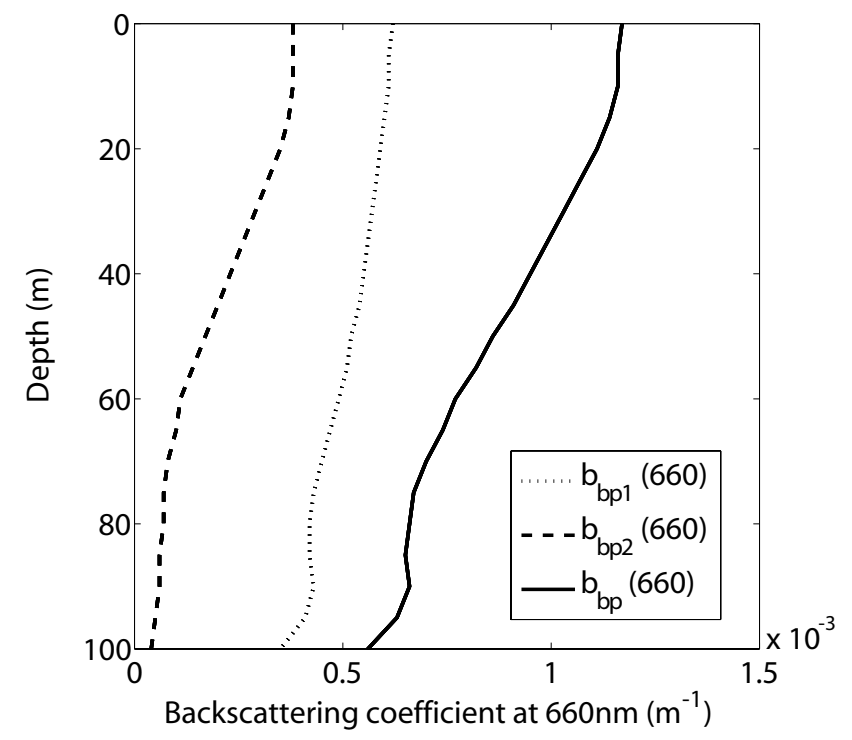

Fig. 8. Modeled vertical profile of backscattering coefficients at $660 \mathrm{~nm}$ by small POC (POC1) $\left(b_{b p 1}(660)\right)$, large POC (POC2) $\left(b_{b p 2}(660)\right)$, and total POC (POC1+POC2) $\left(b_{b p}(660)\right)\left(\mathrm{m}^{-1}\right)$.

atoms $\left(a_{\phi 2}(440)\right)$, indicating low but significant contribution of NAP to the total particulate absorption in the equatorial Pacific (Fig. 6a). The modeled NAP contribution to total particle absorption reproduces the observed increase with depth, from $8 \%$ in the surface and up to $33 \%$ at the bottom of the euphotic layer (120 m depth) (Fig. 6b). The mean NAP contribution to total particle absorption in the euphotic layer is $17 \%$, which is consistent with the measurements of $10-17 \%$ (Dupouy et al., 1997 and 2003; Parslow et al., 1998; Bricaud et al., 2002). The model results of $a_{\phi}(440), a_{\mathrm{NAP}}(440)$ and NAP contribution to total particle absorption all indicate linear increase with depth from the surface to subsurface layer. However, the in-situ measurements show wide horizontal variation in these components, both zonally (Simeon et al., 2003) and meridionally (Dupouy et al., 2003) in the equatorial Pacific, and further observational data of the optical components are necessary for improvement of simulation capability by the optical model.

Colored dissolved organic matter (CDOM) also plays an important role in absorption (e.g., Pegau, 1997; Bricaud et al., 2002; Simeon et al., 2003). We fixed the absorption coefficient by CDOM at $440 \mathrm{~nm}\left(a_{\mathrm{CDOM}}(440)\right)$ vertically to $0.016\left(\mathrm{~m}^{-1}\right)$, within the observed range $\left(0.012-0.019\left(\mathrm{~m}^{-1}\right)\right.$; Simeon et al., 2003). Modeled contribution of CDOM to total absorption at $440 \mathrm{~nm}(a(440))$ is $59-97 \%$ and tends to increase with depth, consistent with the measurements $(50 \%$ at surface and $100 \%$ below chlorophyll maximum; Simeon et al., 2003). CDOM (and DOM) dynamics are not currently included in the model and thus its relative contribution to absorption is determined by the variability of the particulate absorption.

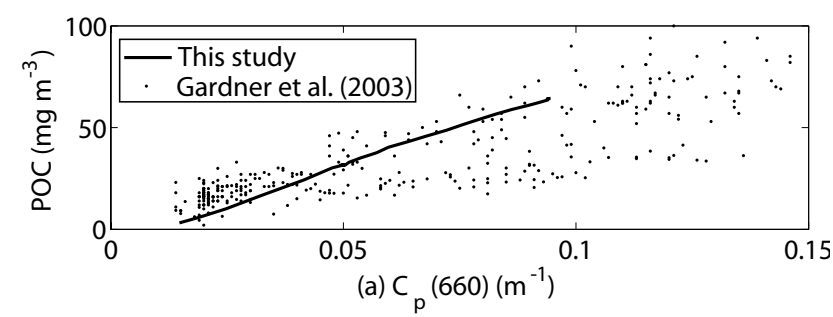

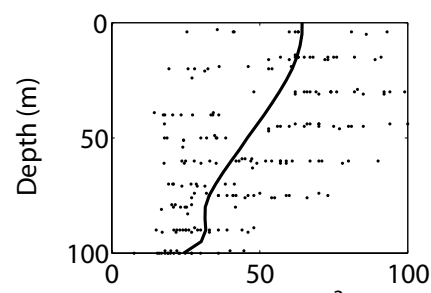

(b) POC $\left(\mathrm{mg} \mathrm{m}^{-3}\right)$

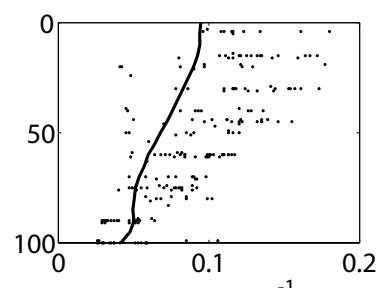

(c) $C_{p}(660)\left(m^{-1}\right)$

Fig. 9. Modeled vertical profile of (a) POC $\left(\mathrm{mg} \mathrm{m}^{-3}\right)$ and (b) beam attenuation coefficient by particles at $660 \mathrm{~nm}\left(C_{p}(660)\right)\left(\mathrm{m}^{-1}\right)$. Dots denote the U.S. JGOFS EqPac data for TT011 and TT012 (Gardner et al., 2003).

\section{Backscattering}

Modeled backscattering coefficients by small and large POC (POC1 and POC2, respectively) at $660 \mathrm{~nm}\left(b_{b p 1}(660)\right.$ and $b_{b p 2}(660)$, respectively) are highest at surface and decrease with depth (Fig. 8). Contribution of POC1 to total particle backscattering is 53-66\%. The contribution of picoplankton to backscattering is less dominant than that to absorption, but it is still higher than that of diatoms because of its small size and larger contribution to POC (Stramski and Kiefer, 1991).

\section{Beam attenuation}

Beam attenuation, especially by particles $\left(c_{p}=a_{p}+b_{p}\right)$, has been often measured in the equatorial Pacific (e.g., Chung et al., 1996; Bishop, 1999; Gardner et al., 2003; Behrenfeld and Boss, 2006). As the contribution of particulate absorption is negligible at $660 \mathrm{~nm}$ (Figs. $3 \mathrm{~b}$ and c), we can assume that $c_{p}$ is due to scattering by particles. The modeled vertical profile of $c_{p}$ is similar to the vertical profiles of backscattering coefficients by particles and POC concentration (Figs. 8 and 9b, c), all of which have the maximum at surface and decrease with depth. Both modeled POC and $c_{p}$ agree with measurements in the equatorial Pacific upwelling region (Fig. 9a), which warrants the applicability of the relation between POC and $c_{p}$ (Eqs. (7) and (8)) to this region.

\subsubsection{Comparison of model results: with and without op- tics}

In ecosystem models that are not coupled to an optical model, values of biogeochemical parameters are tuned to mini- 
mize model-data misfits with vertical profiles of nutrient and chlorophyll concentrations and net community production in the euphotic layer (Figs. 5b, c, d). Vertical profile of PAR was not used to calibrate parameters in previous ecosystem models with constant light attenuation coefficients. Modeled zooplankton biomass and NAP concentration cannot be validated because very few corresponding observational data exist.

In order to examine the value of incorporating a full optical and radiative transfer model into the ecosystem model, we compare two cases, Cases 1 and 2. Case 1 uses only a rudimentary wavelength integrated model for the underwater light field (Eq. 15 below), while Case 2 is the full model using EcoLight to obtain the spectrally resolved underwater light field as described in Sect. 3.1.2.

The model structure in Case 1 was modified from Case 2, as follows. PAR is computed from:

$\operatorname{PAR}(z)\left(\mathrm{Wm}^{-2}\right)=\operatorname{PAR}(0) \times \exp \left\{-k_{1} z-k_{2} \int_{-z}^{0}(\operatorname{Chl} 1(z)+\operatorname{Chl} 2(z)) d z\right\}$,

where $k_{1}$ is the light attenuation coefficient due to water $\left(0.046\left(\mathrm{~m}^{-1}\right)\right)$ and $k_{2}$ is the light attenuation coefficient by chlorophyll $\left(0.048\left(\mathrm{mgChl} \mathrm{m}^{-3}\right)^{-1}\right.$; e.g., Chai et al., 2002). We carry out two case studies with the non-spectral ecosystem model, Cases 1-1 and 1-2.

In Case 1-1, the light attenuation coefficients are set to the same as in Chai et al. (2002) (Table 1). In this case, as in most previous ecosystem modeling studies, observed PAR values and associated decreases with depth are not referred to in tuning model parameters. Therefore, the parameters are tuned to minimize model-data misfits with vertical profiles of nutrient and chlorophyll concentrations and net community production, which requires modification of the microzooplankton maximum specific grazing rate $\left(G 1_{\max }\right)$ from Case 2 by a factor of 1.2 (Table 1). The model results show similar vertical profiles of $\mathrm{Si}(\mathrm{OH})_{4}$ concentration and net community production, relatively low surface $\mathrm{NO}_{3}$ concentration, and higher and deeper chlorophyll maximum, compared with those in Case 2, although the results of both models are within the observations (Figs. 5b, c, d, e). The modeled PAR in Case 1-1 is higher than in Case 2 by a factor of 1.7 and overestimates the observation (Fig. 5a). The modeled surface $\mathrm{NO}_{3}$ concentration and maximal value of chlorophyll concentration cannot be decreased by changing any parameters other than light attenuation coefficients.

In Case 1-2, vertical profiles of PAR, nutrient and chlorophyll concentrations, and net community production are used for tuning model parameters. The light attenuation coefficients are increased relative to those in Chai et al. (2002), by a factor of 1.2 in $k_{1}$ and 1.3 in $k_{2}$ (Table 1), to reproduce observed vertical profiles of PAR. Once the light attenuation coefficients are elevated, we can set values of the other parameters to the same as in Case 2 (Table 1) for the best-fit model results. However, without information for NAP concentration, it is difficult to estimate parameter values associated with zooplankton, such as maximum specific grazing rates, because of pronounced nitrogen flow from zooplankton to NAP via fecal pellets. In Case 2 with the bio-optical model, we tune the maximum specific grazing rates so that the model can reproduce the measured contribution of NAP to absorption by total particles by $10-17 \%$ (Dupouy et al., 1997 and 2003; Parslow et al., 1998; Bricaud et al., 2002) (Fig. 6b), as described in Sect. 3.1.2.

Phytoplankton community assemblage can also be reproduced by the model with optics (Case 2). In Chai et al. (2002), using the non-spectrally-resolved ecosystem model, they tuned the water-column phytoplankton assemblage so that the percentage of diatoms to the total phytoplankton biomass is nearly $16 \%$, referring to the observed ranges from 5\% to 20\% (Bidigare and Ondrusek, 1996). With the spectrally-resolved bio-optical model (Case 2), we could tune vertical phytoplankton assemblage more accurately, referring to not only measurements of each phytoplankton biomass but also those of contribution of diatoms to total phytoplankton derived from optical properties (absorption and backscattering).

These results suggest that both ecosystem model results with or without optics can reproduce the observed fundamental biogeochemical properties in the equatorial Pacific, as long as the correct diffuse light attenuation is used. Since the PAR data are not consistent with the simple chlorophyll formulation previously used in Chai et al. (2002), another source of diffuse light attenuation is needed for the model that can take into account contributions by NAP and CDOM. Our bio-optical model provides such a value.

In addition, the coupled model results illustrate its capability to be constrained using observations of optical variables and thus its ability in improving model performance, which currently cannot be done with available biological properties alone. Additional constituents, which should be added to future ecosystem models, such as DOM, bacteria, and coccoliths (e.g., Fujii and Chai, 2007), are likely to improve the optics-simulation model fit assuming relevant data on their abundance can be obtained.

While we were able to reproduce most of the observations by simply changing the diffuse attenuation values in the model lacking optics (Case 1-2), this approach is not likely to work in temporally varying simulations where the diffuse attenuation coefficient changes in time; any changes in the relative proportion of the biogeochemical variables contributing to absorption (and to a lesser degree to backscattering) would result in changes in the diffuse attenuation parameters in Eq. (15). Simulating these changes requires having the appropriate biogeochemical constituents and related optical properties, most of which are captured by the bio-optical model (with the important exception of CDOM). 
Table 2. Sensitivity of model results to optical parameters: Carbon-specific absorption coefficient by NAP at $440 \mathrm{~nm}\left(a_{\mathrm{NAP}}^{+}(440)\right)$, absorption coefficient by CDOM at $440 \mathrm{~nm}\left(a_{\mathrm{CDOM}}(440)\right)$, background backscattering coefficient $\left(b_{b b g}\right)$, ratio of phytoplankton carbon to POC $\left(R_{\mathrm{POC}}^{\phi}\right)$, backscattering ratio for picoplankton $\left(\tilde{b}_{b_{-} P 1}\right)$, diatoms $\left(\tilde{b}_{b_{-} P 2}\right)$, NAP $\left(\tilde{b}_{b \_\mathrm{NAP}}\right)$, and background particles $\left(\tilde{b}_{b \_b b g}\right)$. Values in parentheses denote model results from a control run with bio-optical model. Euphotic layer depth is defined as a depth of $0.1 \%$ of sea surface.

\begin{tabular}{|c|c|c|c|c|c|c|c|c|c|}
\hline Parameter & $\begin{array}{l}\text { Observed } \\
\text { values }\end{array}$ & $\begin{array}{l}\text { Value for sensitivity } \\
\text { study }\end{array}$ & $\begin{array}{l}\text { Surface } \\
\mathrm{NO}_{3} \\
\left(\mathrm{mmolm}^{-3}\right) \\
(6.6)\end{array}$ & $\begin{array}{l}\text { Surface } \\
\mathrm{Si}(\mathrm{OH})_{4} \\
\left(\mathrm{mmolm}^{-3}\right) \\
(2.2)\end{array}$ & $\begin{array}{l}\text { Maximum } \\
\text { chlorophyll } \\
\left(\mathrm{mgChlm}^{-3}\right) \\
(0.34)\end{array}$ & $\begin{array}{l}\text { Depth of } \\
\text { maximum } \\
\text { chlorophyll } \\
(\mathrm{m}) \\
(50)\end{array}$ & $\begin{array}{l}\text { Mean } \\
a_{\mathrm{NAP}} / a_{p}(440) \\
\text { above } 100 \mathrm{~m} \\
(0.15)\end{array}$ & $\begin{array}{l}\text { Mean } \\
C_{p}(660) \\
\text { above } 100 \mathrm{~m} \\
\left(\mathrm{~m}^{-1}\right) \\
(0.069)\end{array}$ & $\begin{array}{l}\text { Euphotic } \\
\text { layer depth } \\
\text { (m) } \\
(115)\end{array}$ \\
\hline$a_{\mathrm{NAP}}^{+}(440)$ & $0.1^{(1)}$ & $\begin{array}{l}0.07-0.13 \\
(0.1)\end{array}$ & $6.4-6.7$ & $2.0-2.3$ & $0.33-0.35$ & 50 & $0.10-0.20$ & $0.068-0.070$ & 115 \\
\hline$a_{\mathrm{CDOM}}(440)$ & $0.012-0.025^{(2)}$ & $\begin{array}{l}0.011-0.021 \\
(0.016)\end{array}$ & $5.7-7.1$ & $1.7-2.9$ & $0.31-0.38$ & $60-85$ & $0.14-0.17$ & $0.066-0.072$ & $110-120$ \\
\hline$b_{b b g}$ & $0.00017^{(3)}$ & $\begin{array}{l}0.00012-0.00022 \\
(0.00017)\end{array}$ & 6.6 & $2.1-2.2$ & 0.34 & 60 & 0.15 & $0.066-0.071$ & 115 \\
\hline$R_{\mathrm{POC}}^{\phi}$ & $0.25-0.4^{(4)}$ & $\begin{array}{l}0.21-0.39 \\
(0.3)\end{array}$ & $6.5-6.7$ & $2.1-2.2$ & 0.34 & $50-55$ & 0.15 & $0.059-0.086$ & 115 \\
\hline$\tilde{b}_{b_{-} P 1}$ & $0.01-0.013^{(5)}$ & $\begin{array}{l}0.007-0.013 \\
(0.01)\end{array}$ & 6.6 & 2.2 & 0.34 & 50 & 0.15 & $0.065-0.076$ & 115 \\
\hline$\tilde{b}_{b \_} P 2$ & $0.006-0.007^{(6)}$ & $\begin{array}{l}0.004-0.008 \\
(0.006)\end{array}$ & 6.6 & 2.2 & 0.34 & 50 & 0.15 & $0.067-0.073$ & 115 \\
\hline$\tilde{b}_{b \_\mathrm{NAP}}$ & $0.015-0.02^{(5)}$ & $\begin{array}{l}0.011-0.020 \\
(0.015)\end{array}$ & 6.6 & 2.2 & 0.34 & 50 & 0.15 & $0.061-0.083$ & 115 \\
\hline$\tilde{b}_{b \_b b g}$ & $0.02^{(5)}$ & $\begin{array}{l}0.014-0.026 \\
(0.02)\end{array}$ & 6.6 & 2.2 & 0.34 & 50 & 0.15 & $0.067-0.073$ & 115 \\
\hline
\end{tabular}

Sources noted here are: (1) Babin et al., 2003a and b; (2) Simeon et al., 2003; (3) Stramski and Kiefer, 1991; Cho and Azam, 1990, and Behrenfeld and Boss, 2006; (4) Eppley et al., 1992; DuRand et al., 2001; Gundersen et al., 2001, and Oubelkheir et al., 2005; (5) Twardowski et al., 2001; (6) Twardowski et al., 2001, and Boss et al., 2004.

3.2 Optics as a constraint for determining variables and related parameters - sensitivity to optical parameters

The parameter values chosen in this study for the optical model are based on observations (Table 1), but the observed values have substantial variability that arises from environmental and methodological variability. To elucidate how model results are affected by variations in the optical model parameters, we conduct a sensitivity study of the model to those parameters by changing their values individually by $30 \%$ of their standard values. Such variability encompasses the bulk of observed values (Table 2).

We find the model results of biogeochemical properties, i.e., surface $\mathrm{NO}_{3}, \mathrm{Si}(\mathrm{OH})_{4}$, and maximum chlorophyll and its associated depth, to be most sensitive to changes in the absorption coefficient by CDOM at 440nm $\left(a_{\mathrm{CDOM}}(440)\right)$. The surface $\mathrm{NO}_{3}$ increases and $\mathrm{Si}(\mathrm{OH})_{4}$ decreases with the increase of $a_{\mathrm{CDOM}}(440)$, due to an increase in contribution by diatoms when $a_{\mathrm{CDOM}}(440)$ is higher. The maximum chlorophyll decreases and appears at a deeper layer of $85 \mathrm{~m}$ with an $a_{\mathrm{CDOM}}(440)$ increase. These model results reveal that the CDOM concentration strongly affects phytoplankton community structure and its dynamics. While CDOM's inherent effects on backscattering and hence beam attenuation coefficient at $660 \mathrm{~nm}\left(C_{p}(660)\right)$ are negligible, an increase of $a_{\mathrm{CDOM}}(440)$ yields a $C_{p}(660)$ decrease due to a decrease in small algal POC. The modeled euphotic layer depth, de- fined as a depth of $0.1 \%$ light level of sea surface, decreases from $120 \mathrm{~m}$ to $110 \mathrm{~m}$ by varying $a_{\mathrm{CDOM}}(440)$ from 0.011 to $0.021\left(\mathrm{~m}^{-1}\right)$, primarily as a result of enhanced absorption by CDOM. The change of the euphotic layer depth is relatively small because PAR is more controlled by absorption by water than absorption by underwater particle and CDOM concentration. However, the euphotic layer depth is more sensitive to $a_{\mathrm{CDOM}}(440)$ than to the other optical parameters due to significant absorption by CDOM at short wavelengths around $400 \mathrm{~nm}$, at which absorption by water is negligible (Figs. 3a and d).

The observed sensitivity to CDOM concentration is the result of CDOM absorbing light that would otherwise be absorbed by phytoplankton. This effect is more pronounced on picoplankton as they have a relatively higher portion of their energy absorbed in the blue wavelength where CDOM absorbs (they are less packaged and thus have a higher blue to red absorption ratio; Bricaud and Stramski, 1990). Changes in the relative abundance of small and large phytoplankton results in a change in the biogeochemical properties of the upper ocean since their metabolic requirements and interaction with other trophic levels are different.

Variation in other optical parameters also contribute to changes in the model results, but their impact is smaller than that of $a_{\mathrm{CDOM}}(440)$. The carbon-specific absorption coefficient by NAP at $440 \mathrm{~nm}\left(a_{\mathrm{NAP}}^{+}(440)\right)$ has weaker but similar effects on surface nutrient and maximum chlorophyll con- 
centration as $a_{\mathrm{CDOM}}(440)$. The modeled $a_{\mathrm{NAP}} / a_{p}(440)$ is the most sensitive to $a_{\mathrm{NAP}}^{+}(440)$, changing by a factor of 2 from 0.10 to 0.20 . The modeled $C_{p}(660)$ is affected most significantly by the ratio of phytoplankton to particulate organic carbon $\left(R_{\mathrm{POC}}^{\phi}\right)$. The modeled euphotic layer depth does not change from the standard value of $115 \mathrm{~m}$ by changing any optical parameters except for $a_{\mathrm{NAP}}^{+}(440)$, which indicates the important role of absorption in the lower layer below chlorophyll maximum in determining the euphotic layer depth. Varying any of the backscattering ratios, regardless of particle type, does not affect the modeled biogeochemical properties but does influence $C_{p}(660)$. However, the sensitivity of $C_{p}(660)$ to the backscattering ratios depends on particle type, being stronger for NAP and picoplankton and weaker for diatoms and background particles, reflecting the higher backscattering coefficient by picoplankton than by diatoms.

The overall sensitivity study shows that narrowing the observed ranges of optical parameters above is required to reduce uncertainties in reproducing biogeochemical properties. In addition, the above analysis suggests that although the dynamics of neither CDOM nor bacteria are currently incorporated explicitly in the model, embedding CDOM as a state variable in the ecosystem model should be given priority over bacteria to improve simulating bio-optical interactions.

\section{Summary and remarks}

We developed an ecosystem model that explicitly represents biogeochemically and optically two phytoplankton and two zooplankton functional groups, as well as multiple nutrients and non-algal particles (NAP). We applied the model to the equatorial Pacific upwelling region and found that utilizing an optical model to convert from ecosystem model state variables to optical parameters and a realistic subsurface light provides:
(1) more data to compare model output with providing a more rigorous test on model formulation and choice of parameter values, especially for those that are difficult to measure in high resolution in time and space, (2) the required input to obtain a realistic subsurface light field by linking the optics to a radiative-transfer model (Ecolight), and (3) improved simulation realism with respect to key biogeochemical processes, such as photosynthesis, which are crucial for assessing oceanic carbon cycling and food web dynamics. The additional optical measurements, being routinely available from research vessels, autonomous platforms, and space-borne observations, can now be used directly for comparison and testing of the output of our new coupled biooptical model. This is an improvement over the limited number of variables that can be used to test our previous ecosystem models with no explicit optical properties.

Model sensitivity studies on optical parameters suggest that CDOM may have an important role in phytoplankton dynamics, nutrient cycling, and light field in the euphotic layer. Incorporating radiative transfer models to ecosystem models would also contribute to improving the realistic simulations of physical-bio-optical interactions such as chlorophyll modulation of water temperature (e.g., Nakamoto et al., 2000), although these capabilities were not tested here. In the future, real time optical data should be obtained and used in an assimilation mode, increasing the realism of ecosystem simulations such as prediction of the harmful algal bloom dynamics in coastal regions, a prediction that is extremely useful for monitoring near shore water quality and its impact on marine living resources and aquaculture. 


\section{Appendix A}

\section{Physical-ecosystem model}

\section{A1 Governing equations}

The model equations describing each compartment all take the form:

$\frac{\partial C_{i}(z)}{\partial t}\left[\mathrm{mmol} \mathrm{m}^{-3} \mathrm{day}^{-1}\right]$ or $\left[\mathrm{mg} \mathrm{m}^{-3}\right.$ day $\left.^{-1}\right]=\operatorname{PHYSICS}\left(C_{i}(z)\right)+\operatorname{BIOLOGY}\left(C_{i}(z)\right)$,

$i=1, \ldots, 13$.

The model state variables $\left(C_{i}\right)$ are picoplankton $\left(\mathrm{P} 1\left(\mathrm{mmolN} \mathrm{m}^{-3}\right), \mathrm{C} 1\left(\mathrm{mmolC} \mathrm{m}^{-3}\right)\right.$, and $\left.\mathrm{Chl1}\left(\mathrm{mgChl} \mathrm{m}^{-3}\right)\right)$, diatoms $\left(\mathrm{P} 2\left(\mathrm{mmolN} \mathrm{m}^{-3}\right), \mathrm{C} 2\left(\mathrm{mmolC} \mathrm{m}^{-3}\right)\right.$, and $\left.\mathrm{Chl} 2\left(\mathrm{mgChl} \mathrm{m}^{-3}\right)\right)$, microzooplankton $\left(\mathrm{Z} 1\left(\mathrm{mmolN} \mathrm{m}^{-3}\right)\right)$, mesozooplankton $(\mathrm{Z} 2$ $\left.\left(\mathrm{mmolN} \mathrm{m}{ }^{-3}\right)\right)$, nitrate $\left(\mathrm{NO}_{3}\left(\mathrm{mmolN} \mathrm{m}^{-3}\right)\right)$, ammonium $\left(\mathrm{NH}_{4}\left(\mathrm{mmolN} \mathrm{m}^{-3}\right)\right)$, silicate $\left(\mathrm{Si}(\mathrm{OH})_{4}\left(\mathrm{mmolSi} \mathrm{m}^{-3}\right)\right)$, non-algal particles (NAP $\left.\left(\mathrm{mmolN} \mathrm{m}^{-3}\right)\right)$, and biogenic silica $\left(\mathrm{bSiO}_{2}\left(\mathrm{mmolSi} \mathrm{m}^{-3}\right)\right)$.

The term PHYSICS $\left(C_{i}\right)$ represents the contribution to the concentration change due to physical processes, including vertical advection and eddy diffusion:

$\operatorname{PHYSICS}\left(C_{i}(z)\right)\left[\mathrm{mmol} \mathrm{m}^{-3} \mathrm{day}^{-1}\right]$ or $\left[\mathrm{mg} \mathrm{m}^{-3}\right.$ day $\left.^{-1}\right]=\underbrace{-W \frac{\partial C_{i}(z)}{\partial z}}_{\text {advection }}+\underbrace{\frac{\partial}{\partial z}\left(A_{T v} \frac{\partial C_{i}(z)}{\partial z}\right)}_{\text {eddy diffusivity }}$,

where $W$ is vertical velocity, and $A_{T v}$ is vertical coefficient. The values are the same as Chai et al. (2002). The term BIOLOGY $\left(C_{i}\right)$ represents biological sources and sinks of that compartment. In the euphotic zone (the upper $120 \mathrm{~m}$ ), the biological terms, $\operatorname{BIOLOGY}\left(C_{i}\right)$ are:

$\operatorname{BIOLOGY}(\mathrm{P} 1(\mathrm{z}))\left[\mathrm{mmolN} \mathrm{m}^{-3} \mathrm{day}^{-1}\right]=\underbrace{\mathrm{NP} 1(z)+\mathrm{RP} 1(z)}_{\text {growth }}-\underbrace{\mathrm{G}_{1}(z)}_{\text {grazing by Z1 }}$,
$\operatorname{BIOLOGY}(\mathrm{C} 1(\mathrm{z}))\left[\mathrm{mmolC} \mathrm{m}^{-3} \mathrm{day}^{-1}\right]=\underbrace{\mathrm{P}^{\mathrm{C} 1}(z)-\xi_{\mathrm{P} 1}(z)(\mathrm{NP} 1(z)+\mathrm{RP} 1(z))}_{\text {growth }}-\underbrace{\mathrm{G}_{1}(z) \times \frac{\mathrm{C} 1(z)}{\mathrm{P} 1(z)}}_{\text {grazing by Z1 }}$,

$\operatorname{BIOLOGY}(\operatorname{Chl1}(z))\left[\mathrm{mgChl} \mathrm{m}^{-3} \mathrm{day}^{-1}\right]=\underbrace{\rho_{\mathrm{Chl} 1}(z)(\mathrm{NR} 1(z)+\mathrm{RP} 1(z))}_{\text {growth }}-\underbrace{\mathrm{G}_{1}(z) \times \frac{\mathrm{Chl1}(z)}{\mathrm{P} 1(z)}}_{\text {grazing by Z1 }}$,

$\operatorname{BIOLOGY}(\mathrm{P} 2(z))\left[\mathrm{mmolN} \mathrm{m}^{-3} \mathrm{day}^{-1}\right]=\underbrace{\mathrm{NP} 2(z)+\mathrm{RP} 2(z)}_{\text {Growth }}-\underbrace{\mathrm{G}_{2}(z)}_{\text {grazing by Z2 }}-\underbrace{\gamma_{3} \mathrm{P} 2(z)}_{\text {mortality }}-\underbrace{\frac{\partial}{\partial z}\left(W_{1} \mathrm{P} 2(z)\right)}_{\text {sinking }}$,

$\operatorname{BIOLOGY}(\mathrm{C} 2(z))\left[\mathrm{mmolC} \mathrm{m}^{-3} \mathrm{day}^{-1}\right]=\underbrace{\mathrm{P}^{\mathrm{C} 2}(z)-\xi_{\mathrm{P} 2}(z)(\mathrm{NP} 2(z)+\mathrm{RP} 2(z))}_{\text {growth }}-\underbrace{\mathrm{G}_{2}(z) \times \frac{\mathrm{C} 2(z)}{\mathrm{P} 2(z)}}_{\text {grazing by Z2 }}-\underbrace{\frac{\partial}{\partial z}\left(W_{1} \mathrm{C} 2(z)\right)}_{\text {sinking }}-\underbrace{\gamma_{3} \mathrm{C} 2(z)}_{\text {mortality }}$,

$\operatorname{BIOLOGY}(\mathrm{Ch} 12(z))\left[\mathrm{mgChl} \mathrm{m}^{-3} \mathrm{day}^{-1}\right]=\underbrace{\rho_{\mathrm{Chl} 2}(z)(\mathrm{NR} 2(z)+\mathrm{RP} 2(z))}_{\text {growth }}-\underbrace{\mathrm{G}_{2}(z) \times \frac{\mathrm{Ch} 12(z)}{\mathrm{P} 2(z)}}_{\text {grazing by Z1 }}-\underbrace{\frac{\partial}{\partial z}\left(W_{1} \operatorname{Chl} 2(z)\right)}_{\text {sinking }}-\underbrace{\gamma_{3} \operatorname{Chl} 2(z)}_{\text {mortality }}$, 
$\operatorname{BIOLOGY}(\mathrm{Z} 1(z))\left[\mathrm{mmolN} \mathrm{m}^{-3} \mathrm{day}^{-1}\right]=\underbrace{\gamma \mathrm{G}_{1}(z)}_{\text {grazing on P1 }}-\underbrace{\mathrm{G}_{3}(z)}_{\text {predation by Z2 }}-\underbrace{\operatorname{reg}_{1} \mathrm{Z1}(z)}_{\text {excretion }}$,

$\operatorname{BIOLOGY}(\mathrm{Z} 2(z))\left[\operatorname{mmolN~m}^{-3} \mathrm{day}^{-1}\right]=\underbrace{\gamma_{1}\left(\mathrm{G}_{2}(z)+\mathrm{G}_{3}(z)+\mathrm{G}_{4}(z)\right)}_{\text {fecal pellet }}-\underbrace{\operatorname{reg}_{2} \mathrm{Z} 2(z)}_{\text {excretion }}-\underbrace{\gamma_{2} \mathrm{Z2}(z)^{2}}_{\text {loss }}$,

$\operatorname{BIOLOGY}\left(\mathrm{NO}_{3}(z)\right)\left[\mathrm{mmolN} \mathrm{m}^{-3} \mathrm{day}^{-1}\right]=-\underbrace{\mathrm{NP} 1(z)}_{\text {uptake by P1 }}-\underbrace{\mathrm{NP} 2(z)}_{\text {uptake by P2 }}+\underbrace{\gamma_{5} \mathrm{NH}_{4}(z)}_{\text {nitrification }}$,

$\operatorname{BIOLOGY}\left(\mathrm{NH}_{4}(z)\right)\left[\mathrm{mmolN} \mathrm{m}^{-3} \mathrm{day}^{-1}\right]=-\underbrace{\mathrm{RP} 1(z)}_{\text {uptake by P1 }}-\underbrace{\mathrm{RP} 2(z)}_{\text {uptake by P2 }}+\underbrace{\operatorname{reg}_{1} \mathrm{Z1}(z)+\operatorname{reg}_{2} \mathrm{Z} 2(z)}_{\text {excretion }}+\underbrace{\gamma_{7} \mathrm{NAP}(z)}_{\text {PON remineralization }}-\underbrace{\gamma_{5} \mathrm{NH} \mathrm{H}_{4}(z)}_{\text {nitrification }}$,

$\operatorname{BIOLOGY}\left(\mathrm{Si}(\mathrm{OH})_{4}(z)\right)\left[\mathrm{mmolSi} \mathrm{m}^{-3} \mathrm{day}^{-1}\right]=-\underbrace{\mathrm{R}_{\mathrm{SiN}}(\mathrm{NP} 2(z)+\mathrm{RP} 2(z))}_{\text {silicification }}+\underbrace{\gamma_{4} \mathrm{bSiO}_{2}(z)}_{\mathrm{bSiO}_{2} \text { dissolution }}$,

$\operatorname{BIOLOGY}(\operatorname{NAP}(z))\left[\operatorname{mmolN~m}^{-3}\right.$ day $\left.^{-1}\right]=\underbrace{\left(1-\gamma_{0}\right) \mathrm{G}_{1}(z)+\left(1-\gamma_{1}\right)\left(\mathrm{G}_{2}(z)+\mathrm{G}_{3}(z)+\mathrm{G}_{4}(z)\right)}_{\text {fecal pellet }}$

$-\underbrace{\mathrm{G}_{4}(z)}_{\text {grazing by Z2 }}+\underbrace{\gamma_{3} \mathrm{P} 2(z)}_{\mathrm{P} 2 \text { mortality }}-\underbrace{\gamma_{7} \mathrm{NAP}(z)}_{\text {PON remineralization }}-\underbrace{\frac{\partial}{\partial z}\left(W_{2} \mathrm{NAP}(z)\right)}_{\text {sinking }}$

$\operatorname{BIOLOGY}\left(\mathrm{bSiO}_{2}(z)\right)\left[\mathrm{mmolSi} \mathrm{m}^{-3} \mathrm{day}^{-1}\right]=\underbrace{R_{\mathrm{SiN}_{2}(z)}}_{\text {fecal pellet }}-\underbrace{\gamma_{4} \mathrm{bSiO}_{2}(z)}_{\text {dissolution }}+\underbrace{\gamma_{3} R_{\mathrm{SiN}} \mathrm{P} 2(z)}_{\mathrm{P} 2 \text { mortality }}-\underbrace{\frac{\partial}{\partial z}\left(W_{4} \mathrm{bSiO} \mathrm{S}_{2}(z)\right)}_{\text {sinking }}$.

Each biological process is described in the next subsection. See Table 1 for abbreviations.

A2 Formulation of biological processes

( $\mathrm{NO}_{3}$ uptake by picoplankton)

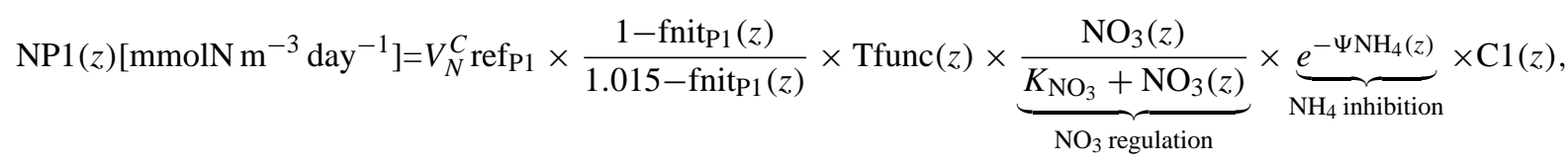

where $V_{N}^{C} \operatorname{ref}_{\mathrm{P} 1}\left[\mathrm{mmolN} \mathrm{mmolC}^{-1} \mathrm{day}^{-1}\right]=\mathrm{P}_{\mathrm{ref}}^{\mathrm{C} 1} \times Q_{\max }$,

$\operatorname{fnit}_{\mathrm{P} 1}(z)=\frac{u Q 1(z)-Q_{\min }}{Q_{\max }-Q_{\min }}$

$u Q 1(z)\left[\operatorname{mmolN} \operatorname{mmolC}^{-1}\right]=\frac{\mathrm{P} 1(z)}{C 1(z)}, Q_{\min }<u Q 1(z)<Q_{\max }$ 
$\operatorname{Tfunc}(z)=\exp \left\{-\frac{E a}{R} \times\left(\frac{1}{\operatorname{Temp}(z)+273.15}-\frac{1}{T_{\text {ref }}}\right)\right\}$.

( $\mathrm{NH}_{4}$ uptake by picoplankton)

$\operatorname{RP1}(z)\left[\operatorname{mmolN~m}^{-3} \mathrm{day}^{-1}\right]=V_{N}^{C} \operatorname{ref}_{\mathrm{P} 1} \times \frac{1-\mathrm{fnit}_{\mathrm{P} 1}(z)}{1.015-\mathrm{fnit}_{\mathrm{P} 1}(z)} \times \operatorname{Tfunc}(z) \times \underbrace{\frac{\mathrm{NH}_{4}(z)}{\mathrm{K}_{\mathrm{NH}_{4}}+\mathrm{NH}_{4}(z)}}_{\mathrm{NH}_{4} \text { regulation }} \times \mathrm{C} 1(z)$.

\section{(Carbon uptake by picoplankton)}

$\mathrm{P}^{\mathrm{C} 1}(z)\left[\mathrm{mmolC} \mathrm{m}^{-3} \mathrm{day}^{-1}\right]=\mathrm{P}_{\mathrm{ref}}^{\mathrm{C} 1} \times \operatorname{fnit}_{\mathrm{P} 1}(z) \times \operatorname{Tfunc}(z) \times\left\{1-\exp \left(\frac{-\alpha \times \theta^{\mathrm{C} 1}(z) \times \operatorname{PAR}(z)}{\mathrm{P}_{\mathrm{ref}}^{\mathrm{C} 1} \times \operatorname{fnit}_{\mathrm{P} 1}(z) \times \operatorname{Tfunc}(z)}\right)\right\} \times \mathrm{C} 1(z)$,

where

$\theta^{\mathrm{Cl}}(z)\left[\mathrm{mgChl} \mathrm{mmolC}{ }^{-1}\right]=\frac{\operatorname{Chl}(z)}{\mathrm{C} 1(z)}$,

$\xi_{\mathrm{P} 1}(z)\left[\mathrm{mmolC} \mathrm{mmolN}{ }^{-1}\right]=\xi_{\mathrm{NO}_{3}} \times \max \left(\frac{\mathrm{NP} 1(z)}{\mathrm{NP} 1(z)+\mathrm{RP} 1(z)}, 0.5\right)$.

\section{(Chlorophyll uptake by picoplankton)}

$\rho_{\mathrm{Chl} 1}(z)\left[\mathrm{mgChl} \mathrm{mmolN}^{-1}\right]=\frac{\theta_{\max }^{N} \times \mathrm{P}_{\mathrm{ref}}^{\mathrm{C} 1} \times \operatorname{fnit}_{\mathrm{P} 1}(z) \times \operatorname{Tfunc}(z) \times\left\{1-\exp \left(\frac{-\alpha \times \theta^{\mathrm{Cl}}(z) \times \operatorname{PAR}(z)}{\mathrm{P}_{\mathrm{ref}}^{\mathrm{Cl}} \times \operatorname{fnnit}_{\mathrm{P} 1}(z) \times \operatorname{Tfunc}(z)}\right)\right\}}{\alpha \times \theta^{\mathrm{C} 1}(z) \times \operatorname{PAR}(z)}$.

( $\mathrm{NO}_{3}$ and $\mathrm{NH}_{4}$ uptake by diatoms)

If $\frac{1}{\mathrm{R}_{\mathrm{SiN}}} \frac{\mathrm{Si}(\mathrm{OH})_{4}(\mathrm{z})}{\mathrm{K}_{\mathrm{Si}(\mathrm{OH})_{4}}+\mathrm{Si}(\mathrm{OH})_{4}(\mathrm{z})}>\frac{\mathrm{NH}_{4}(\mathrm{z})}{\mathrm{K}_{\mathrm{P} 2 \mathrm{NH}_{4}}+\mathrm{NH}_{4}(\mathrm{z})}$,

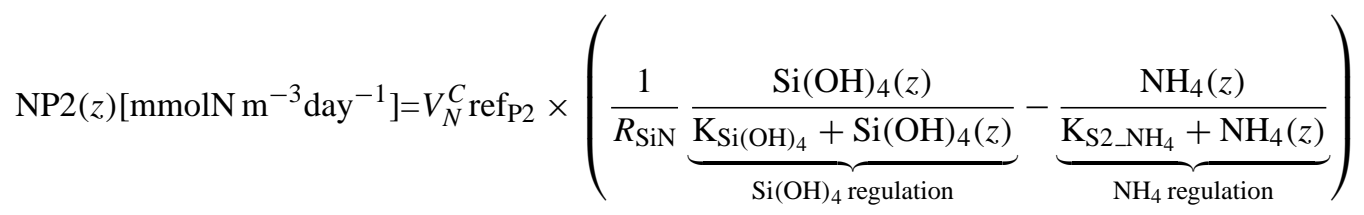

$$
\times \frac{1-\operatorname{fnit}_{\mathrm{P} 2}(z)}{1.015-\operatorname{fnit}_{\mathrm{P} 2}(z)} \times \operatorname{Tfunc}(z) \times \mathrm{C} 2(z),
$$

$\operatorname{RP} 2(z)\left[\operatorname{mmolN~m}^{-3} \mathrm{day}^{-1}\right]=V_{N}^{C} \operatorname{ref}_{\mathrm{P} 2} \times \frac{1-\text { fnit }_{\mathrm{P} 2}(z)}{1.015-\mathrm{fnit}_{\mathrm{P} 2}(z)} \times \operatorname{Tfunc}(z) \times \underbrace{\frac{\mathrm{NH}_{4}(z)}{\mathrm{K}_{\mathrm{S}_{2} \mathrm{NH}_{4}}+\mathrm{NH}_{4}(z)}}_{\mathrm{NH}_{4} \text { regulation }} \times \mathrm{C} 2(z)$,

where

$V_{N}^{C} \operatorname{ref}_{\mathrm{P} 2}\left[\mathrm{mmolN} \mathrm{mmolC}^{-1}\right.$ day $\left.^{-1}\right]=\mathrm{P}_{\mathrm{ref}}^{\mathrm{C} 2} \times Q_{\mathrm{max}}$,

$\operatorname{fnit}_{\mathrm{P} 2}(\mathrm{z})=\frac{\mathrm{uQ} 2(\mathrm{z})-\mathrm{Q}_{\min }}{\mathrm{Q}_{\max }-\mathrm{Q}_{\min }}$, 
$\mathrm{uQ} 2(\mathrm{z})\left[\operatorname{mmolN} \operatorname{mmolC}^{-1}\right]=\frac{\mathrm{P} 2(\mathrm{z})}{\mathrm{C} 2(\mathrm{z})}, \mathrm{Q}_{\min }<\mathrm{uQ} 2(\mathrm{z})<\mathrm{Q}_{\max }$,

If $\frac{1}{\mathrm{R}_{\mathrm{SiN}}} \frac{\mathrm{Si}(\mathrm{OH})_{4}(\mathrm{z})}{\mathrm{K}_{\mathrm{Si}(\mathrm{OH})_{4}}+\mathrm{Si}(\mathrm{OH})_{4}(\mathrm{z})} \leq \frac{\mathrm{NH}_{4}(\mathrm{z})}{\mathrm{K}_{\mathrm{P}_{2} \mathrm{NH}_{4}}+\mathrm{NH}_{4}(\mathrm{z})}$,

$\operatorname{NP} 2(z)=0$,

$\mathrm{RP} 2(z)\left[\mathrm{mmolN} \mathrm{m}^{-3} \mathrm{day}^{-1}\right]=V_{N}^{C} \operatorname{ref}_{\mathrm{P} 2} \times \frac{1}{\mathrm{R}_{\mathrm{SiN}}} \frac{\mathrm{Si}(\mathrm{OH})_{4}(z)}{\mathrm{K}_{\mathrm{Si}(\mathrm{OH})_{4}}+\mathrm{Si}(\mathrm{OH})_{4}(z)} \times \frac{1-\text { fnit }_{\mathrm{P} 2}(z)}{1.015-\text { fnit } 2_{\mathrm{P} 2}(z)} \times \mathrm{Tfunc}(z) \times \mathrm{C} 2(z)$

(Carbon uptake by P2)

$P^{\mathrm{C} 2}(z)\left[\operatorname{mmolC~m}^{-3} \mathrm{day}^{-1}\right]=\mathrm{P}_{\text {ref }}^{\mathrm{C} 2} \times \operatorname{fnit}_{\mathrm{P} 2}(z) \times \operatorname{Tfunc}(z) \times\left\{1-\exp \left(\frac{-\alpha \times \theta^{\mathrm{C} 2}(z) \times \operatorname{PAR}(z)}{\mathrm{P}_{\mathrm{ref}}^{\mathrm{C} 2} \times \operatorname{fnit}_{\mathrm{P} 2}(z) \times \operatorname{Tfunc}(z)}\right)\right\} \times \mathrm{C} 2(z)$,

where

$\theta^{\mathrm{C} 2}(z)\left[\mathrm{mgChl} \mathrm{mmolC}^{-1}\right]=\frac{\mathrm{Chl} 2(z)}{\mathrm{C} 2(z)}$,

$\xi_{\mathrm{P} 2}(z)\left[\mathrm{mmolC} \mathrm{mmolN}{ }^{-1}\right]=\xi_{\mathrm{NO}_{3}} \times \max \left(\frac{\mathrm{NP} 2(z)}{\mathrm{NP} 2(z)+\mathrm{RP} 2(z)}, 0.5\right)$.

(Chlorophyll uptake by P2)

$\rho_{\mathrm{Ch} 12}(z)\left[\mathrm{mgChl} \mathrm{mmolN}^{-1}\right]=\frac{\theta_{\mathrm{max}}^{N} \times \mathrm{P}_{\mathrm{ref}}^{\mathrm{C} 2} \times \operatorname{fnit}_{\mathrm{P} 2}(z) \times \operatorname{Tfunc}(z) \times\left\{1-\exp \left(\frac{-\alpha \times \theta^{\mathrm{C} 2}(z) \times \operatorname{PAR}(z)}{\mathrm{P}_{\mathrm{ref}}^{\mathrm{C} 2} \times \operatorname{fnit}_{\mathrm{P} 2}(z) \times \operatorname{Tfunc}(z)}\right)\right\}}{\alpha \times \theta^{\mathrm{C} 2}(z) \times \operatorname{PAR}(z)}$.

(Grazing on picoplankton by microzooplankton)

$\mathrm{G}_{1}(z)\left[\mathrm{mmolN} \mathrm{m}^{-3} \mathrm{day}^{-1}\right]=\mathrm{G} 1_{\max } \underbrace{\frac{\mathrm{P} 1(z)}{\mathrm{K} 1_{\mathrm{gr}}+\mathrm{P} 1(z)}}_{\text {food limitation }} \underbrace{\frac{\mathrm{P} 1(z)}{\mathrm{P} 1_{\text {ave }}}}_{\text {depth modification }} \mathrm{Z} 1(z)$,

$\mathrm{P} 1_{\mathrm{ave}}\left[\mathrm{mmolN} \mathrm{m}{ }^{-3} \mathrm{day}^{-1}\right]=\frac{1}{Z^{\prime}} \int_{-Z^{\prime}}^{0} \mathrm{P} 1(z) d z$

where $Z^{\prime}$ is the depth of the euphotic zone $(120 \mathrm{~m})$.

(Grazing or predation on diatoms, microzooplankton, and NAP by mesozooplankton)

$\mathrm{G}_{2}(z)\left[\mathrm{mmolN} \mathrm{m}^{-3} \mathrm{day}^{-1}\right]=\mathrm{G} 2{ }_{\max } \frac{\zeta_{1} \mathrm{P} 2(z)}{\mathrm{K} 2_{\mathrm{gr}}+\zeta_{1} \mathrm{P} 2(z)+\zeta_{2} \mathrm{Z} 1(z)+\zeta_{3} \mathrm{NAP}(z)} \mathrm{Z} 2(z)$,

$\mathrm{G}_{3}(z)\left[\mathrm{mmolN} \mathrm{m}^{-3} \mathrm{day}^{-1}\right]=\mathrm{G} 2{ }_{\max } \frac{\zeta_{2} \mathrm{Z} 1(z)}{\mathrm{K} 2_{\mathrm{gr}}+\zeta_{1} \mathrm{P} 2(z)+\zeta_{2} \mathrm{Z} 1(z)+\zeta_{3} \mathrm{NAP}(z)} \mathrm{Z} 2(z)$,

$\mathrm{G}_{4}(z)\left[\mathrm{mmolN} \mathrm{m}^{-3} \mathrm{day}^{-1}\right]=\mathrm{G} 2{ }_{\max } \frac{\zeta_{3} \mathrm{NAP}(z)}{\mathrm{K} 2_{\mathrm{gr}}+\zeta_{1} \mathrm{P} 2(z)+\zeta_{2} \mathrm{Z} 1(z)+\zeta_{3} \mathrm{NAP}(z)} \mathrm{Z} 2(z)$, 
where

$\zeta_{1}=\frac{\rho_{1} \mathrm{P} 2(z)}{\rho_{1} \mathrm{P} 2(z)+\rho_{2} \mathrm{Z} 1(z)+\rho_{3} \mathrm{NAP}(z)}$,

$\zeta_{2}=\frac{\rho_{2} \mathrm{Z} 1(z)}{\rho_{1} \mathrm{P} 2(z)+\rho_{2} \mathrm{Z} 1(z)+\rho_{3} \operatorname{NAP}(z)}$,

$\zeta_{3}=\frac{\rho_{3} \operatorname{NAP}(z)}{\rho_{1} \mathrm{P} 2(z)+\rho_{2} \mathrm{Z} 1(z)+\rho_{3} \operatorname{NAP}(z)}$.

\section{Appendix B}

\section{Chlorophyll-specific absorption coefficients by phyto- plankton in high and low light environments}

We need highest and lowest chlorophyll-specific absorption coefficients by picoplankton ( $a_{\phi 1 \text { (highlight })}^{*}(\lambda)$ and $\left.a_{\phi 1 \text { (low light) }}^{*}(\lambda)\right)$ and diatoms ( $a_{\phi 2 \text { (high light) }}^{*}(\lambda)$ and $\left.a_{\phi 2 \text { (low light) }}^{*}(\lambda)\right)$ to obtain chlorophyll-specific absorption coefficients at each wavelength and depth from Eqs. (1) and (2) in Sect. 2.2. Although many previous studies have measured the chlorophyll-specific absorption coefficients by various phytoplankton species, the values are highly variable, especially for picoplankton in the surface water at around $440 \mathrm{~nm}$ (e.g., Moore et al., 1995; Allali et al., 1997; Culver and Perry, 1999; Ciotti et al., 2002; Devred et al., 2006). This implies complicated small phytoplankton assemblage with different pigment packaging in reality while the small phytoplankton (P1) is represented by one species (picoplankton) in the model. In addition, the measured specific absorption coefficient by small phytoplankton is often obtained by dividing the absorption coefficient by not only chlorophyll but also other pigments such as pheophytin (pheopigments).

The highest chlorophyll-specific absorption coefficient by diatoms at $440 \mathrm{~nm}$ ( $\left.a_{\phi 2 \text { (high light) }}^{*}(440)\right)$ is set to 0.012 $\left(\mathrm{m}^{2} \mathrm{mg}^{-1}\right)$, based on an observed mean value of microplankton in the surface water (Fig. 7 in Ciotti et al., 2002). We assume that a ratio of highest to lowest chlorophyll-specific absorption coefficient at $440 \mathrm{~nm}$ in the equatorial Pacific is around 1.5 for each phytoplankton, attributing to observed chlorophyll-specific absorption coefficients by total phytoplankton at $440 \mathrm{~nm}$ in each depth, which varies from 0.07 $\left(\mathrm{m}^{2} \mathrm{mg}^{-1}\right)$ in the surface water $\left(a_{\phi}^{*}\right.$ (high light) $\left.(440)\right)$ to 0.045 $\left(\mathrm{m}^{2} \mathrm{mg}^{-1}\right)$ at the bottom of the euphotic layer ( $a_{\phi \text { (low light) }}^{*}$ (440)) (Fig. 5 in Allali et al., 1997). Therefore, $a_{\phi 2 \text { (low light) }}^{*}$ (440) is estimated to be about $0.008\left(\mathrm{~m}^{2} \mathrm{mg}^{-1}\right)$. We also assume that a ratio of picoplankton to total phytoplankton chlorophyll and that of diatoms to total phytoplankton chlorophyll are around 0.83 and 0.17 , respectively, and are uniform with depth (e.g., Chavez, 1989; Peña et al., 1990;
Bidigare and Ondrusek, 1996). Based on Ciotti et al. (2002), Devred et al. (2006) reconstructed the specific absorption spectra of phytoplankton communities as a linear combination of absorption spectra of small and large cells:

$a_{\phi}^{*}(\lambda, z)\left[\mathrm{m}^{2} \mathrm{mg}^{-1}\right]=F a_{\phi 1}^{*}(\lambda, z)+(1-F) a_{\phi 2}^{*}(\lambda, z)$,

where $F$ is the phytoplankton size fraction.

With the assumption above, we estimate highest and lowest chlorophyll-specific absorption coefficients by picoplankton at $440 \mathrm{~nm}\left(a_{\phi 1 \text { (high light) }}^{*}(440)\right.$ and $a_{\phi 1 \text { (low light) }}^{*}(440)$, respectively) as follows:

$$
\begin{aligned}
& a_{\phi 1 \text { (high light) }}^{*}(440)\left[\mathrm{m}^{2} \mathrm{mg}^{-1}\right]= \\
& \quad \frac{\left\{a_{\phi \text { (high light })}^{*}(440)-0.17 \times a_{\phi 2 \text { (high light })}^{*}(440)\right\}}{0.83}, \\
& a_{\phi 1 \text { (low light) }}^{*}(440)\left[\mathrm{m}^{2} \mathrm{mg}^{-1}\right]= \\
& \quad \frac{\left\{a_{\phi \text { (low light) }}^{*}(440)-0.17 \times a_{\phi 2 \text { (low light) }}^{*}(440)\right\}}{0.83} .
\end{aligned}
$$

From these equations, we derive $a_{\phi 1 \text { (high light) }}^{*}$ (440) of 0.082 $\left(\mathrm{m}^{2} \mathrm{mg}^{-1}\right)$ and $\left.a_{\phi 1 \text { (low light) }}^{*}(440)\right)$ of $0.053\left(\mathrm{~m}^{2} \mathrm{mg}^{-1}\right)$, which agree well with the observed chlorophyll-specific absorption coefficients by picoplankton (e.g., Ciotti et al., 2002). The highest and lowest chlorophyll-specific absorption coefficients by picoplankton and diatoms at other wavelengths are derived by fitting spectral profiles of Ciotti and Bricaud (2006) and Ciotti et al. (2002), respectively, to coincide at $440 \mathrm{~nm}$.

Acknowledgements. The authors wish to thank K. Fennel and an anonymous reviewer for their constructive comments. Funding for this work was provided by the Ocean Optics and Biology Program of the Office of Naval Research under grant number of N0001405-1-0322. M. Fujii was supported by MEXT through Special Coordination Funds for Promoting Science and Technology.

Edited by: Minhan Dai 


\section{References}

Allali, K., Bricaud, A., and Claustre, H.: Spatial variations in the chlorophyll-specific absorption coefficients of phytoplankton and photosynthetically active pigments in the equatorial Pacific, J. Geophys. Res., 102(C6), 12 413-12 423, 1997.

Babin, M., Morel, A., Fournier-Sicre, V., Fell, F., and Stramski, D.: Light scattering properties of marine particles in coastal and open ocean waters as related to the particle mass concentration, Limnol. Oceanogr., 48(2), 843-859, 2003a.

Babin, M., Stramski, D., Ferrari, G. M., Claustre, H., Bricaud, A., Obolensky, G., and Hoepffner, N.: Variations in the light absorption coefficients of phytoplankton, nonalgal particles, and dissolved organic matter in coastal waters around Europe, J. Geophys. Res. 108(C7), 3211, doi:10.1029/2001JC000882, 2003b.

Barber, R. T., Sanderson, M. P., Lindley, S. T., Chai, F., Newton, J., Trees, C. C., Foley, D. G., and Chavez, F. P.: Primary productivity and its regulation in the equatorial Pacific during and following the 1991-1992 El Niño, Deep-Sea Res. II, 43(4-6), 933-969, 1996.

Behrenfeld, M. J. and Boss, E.: Beam attenuation and chlorophyll concentration as alternative optical indices of phytoplankton biomass, J. Mar. Res., 64, 431-451, 2006.

Behrenfeld, M. J., Boss, E., Siegel, D. A., and Shea, D. M.: Carbon-based ocean productivity and phytoplankton physiology from space, Global Biogeochem. Cy., 19, GB1006, doi:10.1029/2004GB002299, 2005.

Behrenfeld, M. J. and Falkowski, P. G.: Photosynthetic rates derived from satellite-based chlorophyll concentration, Limnol. Oceanogr., 42, 1-20, 1997.

Bidigare, R. R. and Ondrusek, M. E.: Spatial and temporal variability of phytoplankton pigment distributions in the central equatorial Pacific Ocean, Deep-Sea Res. II, 43(4-6), 809-833, 1996.

Bishop, J. K. B.: Transmissometer measurement of POC, Deep-Sea Res. I, 46, 355-369, 1999.

Bissett, W. P., Carder, K. L., Walsh, J. J., and Dieterle, D. A.: Carbon cycling in the upper waters of the Sargasso Sea: II. Numerical simulation of apparent and inherent optical properties, DeepSea Res. I, 46, 271-317, 1999.

Boss, E., and Pegau, W. S.: The relationship of light scattering at an angle in the backward direction ot the backscattering coefficient, Appl. Opt., 40, 5503-5507, 2001.

Boss, E., Pegau, W. S., Lee, M., Twardowski, M. S., Shybanov, E., Korotaev, G.., and Baratange, F.: The particulate backscattering ratio at LEO 15 and its use to study particles composition and distribution. J. Geophys. Res., 109(C1), C01014, doi:10.1029/2002JC001514, 2004.

Bricaud, A., Morel, A., and Prieur, L.: Optical efficiency factors of some phytoplankters, Limnol. Oceanogr., 28, 816-832, 1983.

Bricaud, A., Roesler, C. S., Parslow, J. S., and Ishizaka, J.: Biooptical studies during the JGOFS-equatorial Pacific program: a contribution to the knowledge of the equatorial system, Deep-Sea Res. II, 49, 2583-2599, 2002.

Bricaud, A. and Stramski, D: Spectral absorption coefficients of living phytoplankton and nonalgal biogenous matter: A comparison between the Peru upwelling area and the Sargasso Sea, Limnol. Oceanogr., 35, 562-582, 1990.

Chai, F., Dugdale, R. C., Peng, T.-H., Wilkerson, F. P., and Barber, R. T.: One-dimensional ecosystem model of the equatorial Pacific upwelling system. Part I: model development and silicon and nitrogen cycle, Deep-Sea Res. II, 49, 2713-2745, 2002.

Chai, F., Barber, R. T., and Lindley, S. T.: Origin and maintenance of high nutrient condition in the equatorial Pacific, Deep-Sea Res. II, 42(4-6), 1031-1064, 1996.

Chavez, F. P.: Size distribution of phytoplankton in the central and eastern tropical Pacific, Global Biogeochem. Cy., 3, 27-35, 1989.

Chavez, F. P., Buck, K. R., Coale, K. H., Martin, J. H., DiTullio, G. R., Welshmeyer, N. A., Jacobson, A. C., and Barber, R. T.: Growth rates, grazing, sinking and iron limitation of equatorial Pacific phytoplankton, Limnol. Oceanogr., 36, 1816-1833, 1991.

Cho, B. C. and Azam, F.: Biogeochemical significance of bacterial biomass in the ocean's euphotic zone, Mar. Ecol. Prog. Ser., 63, 253-259, 1990.

Chung, S. P., Gardner, W. D., Richardson, M. J., Walsh, I. D., and Landry, M.R.: Beam attenuation and microorganisms: Spatial and temporal variations in small particles along $140^{\circ} \mathrm{W}$ during 1992 JGOFS-EqPac transects, Deep-Sea Res. II, 43, 1205-1226, 1996.

Ciotti, A. M. and Bricaud, A.: Retrievals of a size parameter for phytoplankton and spectral light absorption by colored detrital matter from water-leaving radiances at SeaWiFS channels in a continental shelf region off Brazil, Limnol. Oceanogr. Methods, 4, 237-253, 2006.

Ciotti, A. M., Lewis, M. R., and Cullen, J. J.: Assessment of the relationship between dominant cell size in natural phytoplankton communities and the spectral shape of the absorption coefficient, Limnol. Oceanogr., 47(2), 404-417, 2002

Cloern, J. E., Grenz, C., and Vidergar-Lucas, L.: An empirical model of the phytoplankton chlorophyll:carbon ratio - the conversion factor between productivity and growth rate, Limnol. Oceanogr., 40(7), 1313-1321, 1995.

Culver, M. E. and Perry, M. J.: The response of photosynthetic absorption coefficients to irradiance in culture and in tidally mixed estuarine waters, Limnol. Oceanogr., 44(1), 24-36, 1999.

Denman, K. L.: Modelling planktonic ecosystems: parameterizing complexity, Prog. Oceanog., 57, 429-452, 2003.

Denman, K. L. and Peña, M. A.: The response of two coupled onedimensional mixed layer/planktonic ecosystem models to climate change in the NE subarctic Pacific Ocean, Deep Sea Res. II, 49, 5739-5757, 2002.

Devred, E., Sathyendranath, S., Stuart, V., Maass, H., Ulloa, O., and Platt, T.: A two-component model of phytoplankton absorption in the open ocean: Theory and applications, J. Geophys. Res., 111, C03011, doi:10.1029/2005JC002880, 2006.

Dickey, T. D., Lewis, M. R., and Chang, G. C.: Optical oceanography: recent advances and future directions using global remote sensing and in situ observations, Rev. Geophys., 44(1), RG1001, doi:10.1029/2003RG000148, 2006.

Dupouy, C. Loisel, H., Neveux, J., Brown, S. L., Moulin, C., Blanchot, J., Le Bouteiller, A., and Landry, M. R.: Microbial absorption and backscattering coefficients from in situ and POLDER satellite data during an El Niño-Southern Oscillation cold phase in the equatorial Pacific $\left(180^{\circ}\right)$, J. Geophys. Res., 108(C12), 8138, doi:10.1029/2001JC001298, 2003.

Dupouy, C., Neveux, J., and André, J. M.: Spectral absorption coefficient of photosynthetically active pigments in the equatorial Pacific Ocean $\left(165^{\circ} \mathrm{E}-150^{\circ} \mathrm{W}\right)$, Deep-Sea Res. II, 44(9-10), 1881-1906, 1997. 
DuRand, M. D., Olson, R. J., and Chisholm, S. W.: Phytoplankton population dynamics at the Bermuda Atlantic Time-series station in the Sargasso Sea, Deep-Sea Res. II, 48, 1983-2003, 2001.

Duysens, L. M. N.: The flattering effect of the absorption spectra of suspentions as compared to that of solutions, Biochem. Biophys. Acta, 19, 1-12, 1956.

Eppley, R. W., Chavez, F. P., and Barber, R. T.: Standing stocks of particulate carbon and nitrogen in the Equatorial Pacific at $150^{\circ}$ W, J. Geophys. Res., 97, 655-661, 1992.

Falkowski, P. G., Dubinsky, Z., and Wyman, K.: Growth-irradiance relationships in phytoplankton, Limnol. Oceanogr., 30, 311-321, 1985.

Fournier, G., and Forand, J. L.: Analytic phase function for ocean water, in: Ocaen Optics XII, edited by: Jaffe, J. S., Proc. SPIE, 2258, 194-201, 1994.

Friedrichs, M. A. M., Dusenberry, J. A., Anderson, L. A., Armstrong, R., Chai, F., Christian, J. R., Doney, S. C., Dunne, J., Fujii, M., Hood, R., McGillicuddy, D., Moore, J. K., Schartau, M., Spitz, Y. H., and Wiggert, J. D.: Assessment of skill and portability in regional marine biogeochemical models: the role of multiple planktonic groups, J. Geophys. Res., 112, C08001, doi:10.1029/2006JC003852, 2007.

Fujii, M. and Chai, F.: Modeling carbon and silicon cycling in the equatorial Pacific, Deep-Sea Res. II, 54, 496-520, doi:10.1016/j.dsr2.2006.12.005, 2007.

Gardner, W. D., Jo Richardson, M., Carlson, C. A., Hansell, D., and Mishonov, A. V.: Determining true particulate organic carbon: bottles, pumps and methodologies, Deep-Sea Res. II, 50, 655-674, 2003.

Geidar, R. J.: Light and temperature dependence of the carbon to chlorophyll a ratio in microalgae and cynobacteria: implications for physiology and growth of phytoplankton, New Phytol., 106, 1-34, 1987.

Geidar, R. J., MacIntyre, H. L., and Kana, T. M., A dynamic regulatory model of phytoplanktonic acclimation to light, nutrients, and temperature, Limnol. Oceanogr., 43, 679-694, 1998.

Gregg, W. W. and Carder, K. L.: A simple spectral solar irradiance model for cloudless marine atmospheres, Limnol. Oceanogr., 35, 1657-1675, 1990.

Gregg, W. W., Ginoux, P., Schopf, P. S., and Casey, N. W.: Phytoplankton and iron: validation of a global three-dimensional ocean biogeochemical model, Deep-Sea Res. II, 50, 3143-3169, 2003.

Gunderson, K., Orcutt, K. M., Purdie, D. A., Michaels, A. F., and Knap, A. H.: Particulate organic carbon mass distribution at the Bermuda Atlantic time-series Study (BATS) site, Deep-Sea Res. II, 48, 1697-1718, 2001.

IOCCG: Remote sensing of inherent optical properties: Fundamentals, test of algorithms, and applications, edited by: Lee, Z.P., Reports of the international ocean-colour coordinating group, No. 5, IOCCG, Dartmouth, Canada, 2006.

Iturriaga, R. and Siegel, D. A.: Microphotometric characterization of phytoplankton and detrital absorption properties in the Sargasso Sea, Limnol. Oceanogr., 34(8), 1706-1726, 1989.

Jiang, M.-S., Chai, F., Dugdale, R. C., Wilkerson, F. P., Peng, T.-H., and Barber, R. T.: A nitrate and silicate budget in the equatorial Pacific Ocean: a coupled physical-biological model study, DeepSea Res. II, 50, 2971-2996, 2003.

Lancelot, C., Spitz, Y. H., Gypens, N., Ruddick, K., Becquevort, S., Rousseau, V., and Billen, G.: Modelling diatom-Phaeocystis blooms and nutrient cycles in the Southern Bight of the North Sea: the MIRO model, Mar. Ecol. Prog. Ser., 289, 63-78, 2005.

Mobley, C. D. and Sundman, L. K.: Hydrolight 4.1 User's Guide (Sequoia Scientific, Inc., Redmond, Wash.), 2000a.

Mobley, C. D. and Sundman, L. K.: Hydrolight 4.1 Technical Documentation (Sequoia Scientific, Inc., Redmond, Wash.), $2000 \mathrm{~b}$.

Mobley, C. D., Sundman, L. K., and Boss, E.: Phase function effects on oceanic light fields, Appl. Opt., 41(6), 1035-1050, 2002.

Moore, J. K., Doney, S. C., Kleypas, J. A., Glover, D. M., and Fung, I. Y.: An intermediate complexity marine ecosystem model for the global domain, Deep-Sea Res. II, 49, 403-462, 2002.

Moore, L. R., Goericke, R., and Chisholm, S. W.: Comparative physiology of Synechococcus and Prochlorococcus: influence of light and temperature on growth, pigments, fluorescence and absorptive properties, Mar. Ecol. Prog. Ser., 116, 259-275, 1995.

Morel, A.: Optical properties of pure water and pure seawater, in: Optical Aspects of Oceanography, edited by: Jerlov, N. G. and Nielsen, E. S., Academic, New York, 1-24, 1974.

Mueller, J. L. and Lange, R. E.: Bio-optical provinces of the northeast Pacific Ocean: a provisional analysis, Limnol. Oceanogr., 34, 1572-1586, 1989.

Murray, J. W., Johnson, E., and Garside, C.: A US JGOFS process study in the equatorial Pacific (EqPac): Introduction., Deep-Sea Res. II, 42(2-3), 275-293, 1995.

Nakamoto, S., Kumar, S. P., Oberhuber, J. M., Muneyama, K., and Frouin, R.: Chlorophyll modulation of sea surface temperature in the Arabian Sea in a mixed-layer isopycnal general circulation model, Geophys. Res. Lett., 27(6), 747-750, 2000.

Oubelkheir, K., Claustre, H., Sciandra, A., and Babin, M. Bio-optical and biogeochemical properties of different trophic regimes in oceanic waters, Limnol. Oceanogr., 50, 1795-1809, 2005.

Pacanowski, R.C. and Philander, S. G. H.:, Parameterization of vertical mixing in numerical models of tropical oceans, J. Phys. Oceanogr., 11, 1443-1451, 1981.

Parslow, J. S., Clementson, L. A., Turnbull, A. R., and McKenzie, D. C.: Bio-optical characteristics of oceans around Australia, in: Ocean Optics XIV Conferece Papers, Vol. 1, Hawaii, November 1998.

Pegau, W. S.: The distribution of colored dissolved organic matter $(\mathrm{CDOM})$ in the Equatorial Pacific, in: Ocean Optics XIII, edited by: Ackleson, S. G. and Frouin, R., 2963, 508-513, 1997.

Peña, M. A., Lewis, M. R., and Harrison, W. G.: Primary productivity and size structure of phytoplankton biomass on a transect of the equator at $135^{\circ} \mathrm{W}$ in the Pacific Ocean, Deep-Sea Res., 37, 295-315, 1990.

Pope, R. M. and Fry, E. S.: Absorption spectrum (280-700 nm) of pure water. II. Integrating cavity measurements, Appl. Opt., 36, 8710-8723, 1997.

Riley, G. A., Stommel, H., and Bumpus, D. F.: Quantitative ecology of the plankton of the western North Atlantic, Bulletin of the Bingham Oceanographic Collection Yale University, 12, 1-169, 1949.

Roesler, C. S., Perry, M. J., and Carder, K. L.: Modeling in situ phytoplantkon absorption from total absorption spectra in productive inland marine waters, Limnol. Oceanogr., 34, 1510-1523, 1989.

Rothstein, L. M., Cullen, J. J., Abbott, M., Chassignet, E. P., Denman, K., Doney, S. C., Ducklow, H., Fennel, K., Follows, M., Haidvogel, D., Hoffman, E., Karl, D. M., Kindle, J., Lima, I., 
Maltrud, M., McClain, C., McGillicuddy, D., Olascoaga, M. J., Spitz, Y., Wiggert, J., and Yoder, J.: Modeling ocean ecosystems - The paradigm program, Oceanography, 19(1), 22-51, 2006.

Rudnick, D. L. and Perry, M. J.: ALPS: Autonomous and Lagrangian Platforms and Sensors, Workshop Report, 64 pp., 2003.

Schartau, M. and Oschlies, A.: Simultaneous data-based optimization of a 1D-ecosystem model at three locations in the North Atlantic: Part I - Method and parameter estimates, J. Mar. Res., 61, 765-793, 2003.

Siegel, D. A., Maritorena, S., Nelson, N. B., Hansell, D. A., Lorenzi-Kayser, M.: Global distribution and dynamics of colored dissolved and detrital organic materials, J. Geophys. Res., 107(C12), 3228, doi:10.1029/2001JC000965, 2002.

Simeon, J., Roesler, C., Pegau, W. S., and Dupouy, C.: Sources of spatial variability in light absorbing components along an equatorial transect from $165^{\circ} \mathrm{E}$ to $150^{\circ} \mathrm{W}$, J. Geophys. Res.,
108(C10), 3333, doi:10.1029/2002JC001613, 2003.

Stramski, D., Boss, E., Bogucki, D., and Voss, K. J.: The role of seawater constituents in light backscattering in the ocean, Prog. Oceanogr., 61(1), 27-55, 2004.

Stramski, D. and Kiefer, D. A.: Light scattering by microzooorganisms in the open ocean, Prog. Oceanogr., 28, 343-383, 1991.

Stramski, D., Reynolds, R. A., Kahzu, M., and Mitchell, B. G.: Estimation of particulate organic carbon in the ocean from satellite remote sensing, Science, 285(5433), 239-242, 1999.

Twardowski, M. S., Boss, E., Macdonald, J. B., Pegau, W. S., Barnard, A. H., and Zaneveld, J. R.: A model for estimating bulk refractive index from the optical backscattering ratio and the implications for understanding particle composition in case I and case II waters, J. Geophys. Res., 106, 14 129-14 142, 2001.

Wyrtki, K.: An estimate of equatorial upwelling in the Pacific, J. Phys. Oceanogr., 11, 1205-1214, 1981. 